\title{
Nuclear Magnetic Resonance (NMR) Examination of Fossilized, Semi-fossilized, and Modern Resins from the Caribbean Basin and Surrounding Regions ${ }^{1}$
}

\author{
Joseph B. Lambert ${ }^{2}$, Jorge A. Santiago-Blay ${ }^{3}$, Reniel Rodríguez Ramos ${ }^{4}$, \\ Yuyang $\mathrm{Wu}^{5}$, and Allison J. Levy ${ }^{2}$
}

\begin{abstract}
Amber, copal, and modern resins from the Caribbean Basin and surrounding regions have been characterized by carbon and proton nuclear magnetic resonance spectroscopy. Amber is characterized by broader spectra, in contrast to copal and modern resins, which have sharper spectra. Many alleged amber samples analyzed in the present study proved to be copal. Genuine amber raw materials from the Caribbean Basin have spectra that are broadly consistent with mine sources in Chiapas (Mexico), the Dominican Republic, and northwestern Venezuela. More particularly, amber artifacts from Puerto Rico have spectra that are more consistent with the Dominican spectra and artifacts from northern Colombia than with the Mexican and Venezuelan spectra.
\end{abstract}

Key Words: Amber, Archaeology, Caribbean Basin, Copal, Modern resins, Nuclear Magnetic Resonance (NMR) spectroscopy, Trans-Caribbean pre-Columbian contacts

The Dominican Republic in the Caribbean has long been known to be a rich geological source of fossilized plant resin known as amber (Fraquet 1987; Langenheim 2003; Rice 2006; Iturralde-Vinent 2001; Iturralde-Vinent and Harstein 1998). Archaeological evidence for its pre-Columbian use in the insular Caribbean region has been scarce, as the record is restricted to a small number of specimens recovered from sites in Cuba, Hispaniola, and Puerto Rico (Figure 1) (Veloz Maggiolo et al. 1972; Alegría 1980; Vega 1987; Rodríguez López 1991a; Valcárcel Rojas 2012). Even though sourcing studies generally are absent, the provenance of these amber artifacts has been attributed invariably to Hispaniola (e.g. Walker 1985; Rodríguez López 1991b), despite evidence for the existence of sources and artifacts of amber in other Circum-Caribbean locations, including the state of Chiapas in southeastern Mexico (Lee Whiting 2005, Lowe 2001), central and northwestern Venezuela (Sanoja and Vargas 1967, 1999; Wagner 1984), and northern Colombia (Anderson and Bray 2006;

\footnotetext{
${ }^{1}$ Submitted on October 3, 2014. Accepted on October 16, 2014. Last revisions received on November 8, 2014.

${ }^{2}$ Department of Chemistry, Trinity University, One Trinity Place, San Antonio, Texas 78212-1200 USA. E-mail: jlambert@northwestern.edu

3 Department of Paleobiology, National Museum of Natural History, Washington, District of Columbia 20560 USA. E-mail: blay@ si.edu

${ }^{4}$ Programa de Ciencias Sociales, Universidad de Puerto Rico, Recinto de Utuado, Utuado, Puerto Rico 00641-2500 USA. E-mail: renielrodriguez@ gmail.com

5 Department of Chemistry, Northwestern University, 2145 Sheridan Road, Evanston, Illinois, 60208-3113 USA. E-mail: y-wu1@ northwestern.edu
}

DOI: 10.9784/LEB2(4)Lambert.01

Electronically available on January 10, 2015. Mailed on January 10, 2015. 
Mason 1931; Wassen 1955). Consideration of these other areas as potential amber sources opens the door for the possibility of additional pre-Columbian vectors of interactions in the Caribbean Basin through which this material could have been transported into the islands. Since there are no known amber sources in northeastern Venezuela and the Lesser Antilles, the trans-Caribbean circulation of this material from Mexico, Colombia, and northwest and north central Venezuela must be evaluated in addition to traditional concepts of trade from the South American mainland via island-hopping to the north (Rouse 1992).

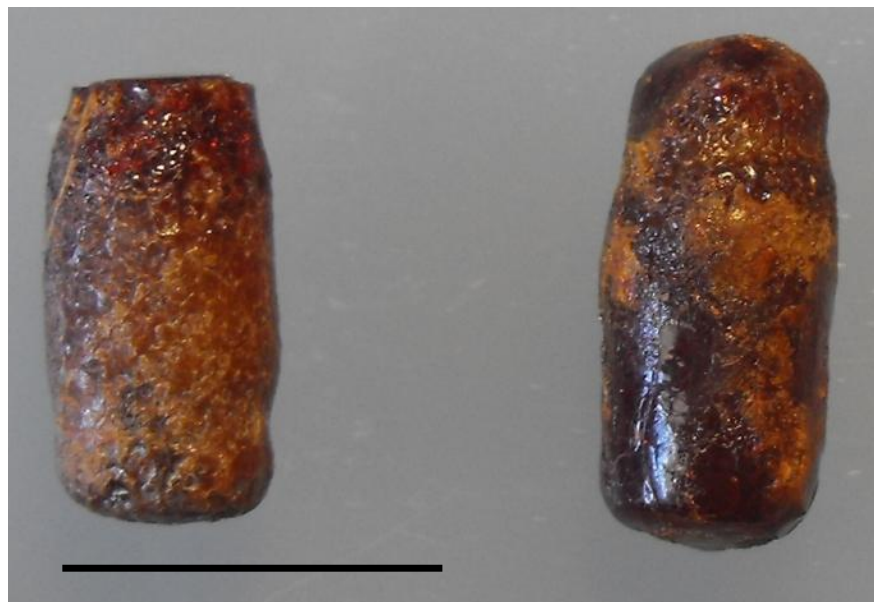

Figure 1. Amber earspools from the Chorro de Maita site, Cuba. Courtesy of Roberto Valcárcel Rojas. Scale bar represents $1 \mathrm{~cm}$.

Amber is particularly amenable to interaction studies in archaeology, as it can be characterized by various physical methods, including nuclear magnetic resonance (NMR) spectroscopy and mass spectrometry (MS) (Labandeira 2014; Lambert et al. 1995, 2002, 2008, 2014). This process of analysis potentially can distinguish not only paleobotanical sources, but also geographical provenance and degrees of maturity of the resin. This study was carried out to explore geological sources of amber within the Caribbean Basin, including surrounding territories (Figure 2) as potential sources for archaeological specimens recovered from two sites: Punta Candelero in eastern Puerto Rico and Nahuange, nestled in the Caribbean portion of north central Colombia. We have endeavored to procure geological samples from as many primary amber sources as possible from museums, botanical gardens, arboreta, and private collections. It has been possible to examine materials from Mexico, Central America, the Caribbean, northern/central South America, and the southern parts of the United States. We report herein the results of these investigations and their implications for trade patterns in the Caribbean region. 


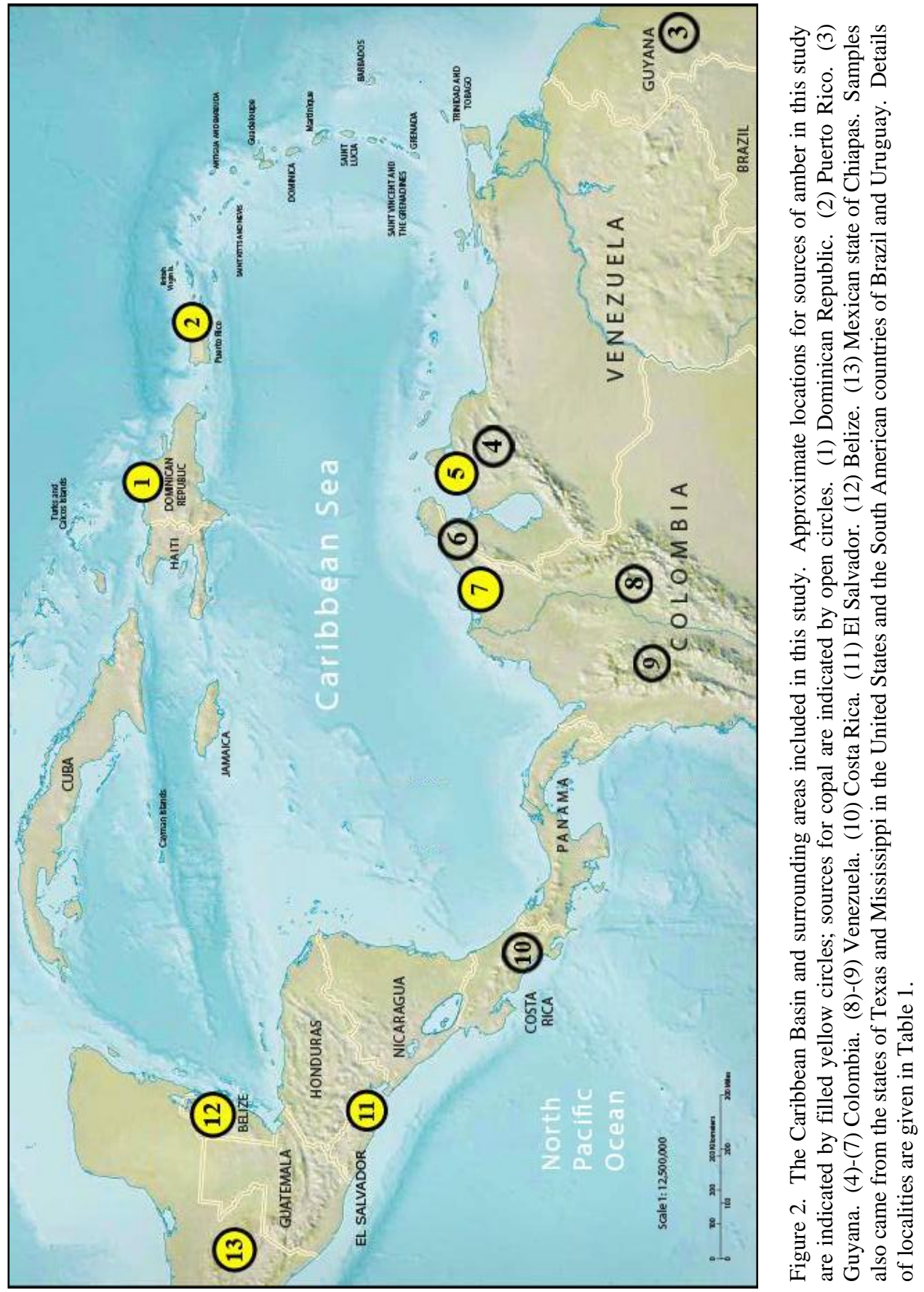


Paleobotanical Sources. Examination of fossilized resins by molecular spectroscopic methods has yielded five categories, which differ in their molecular constituency (Lambert et al. 2008). Whereas MS identifies specific molecules to realize these distinctions, NMR spectroscopy examines the overall spectral pattern of either the carbon atoms or the hydrogen atoms that constitute the bulk. The two methods generated the same five categories, two of which are worldwide. NMR Group A has representatives from North America, Europe, Asia (from Lebanon to Japan), Australia, and New Zealand. These materials derived from ancient varieties of conifers such as the Araucariaceae or related families (Poinar et al. 2007). Group B has representatives from North America, India, Southeast Asia, and Australia. They derived from ancient flowering plants, possibly the family Dipterocarpaceae (Lambert et al. 2013). Group D has representatives from Mexico, the Caribbean, South America, and Africa. They derived from ancient flowering plants from the family Fabaceae (Langenheim 2003). Groups C and E are smaller and not of relevance to this study. This categorization was derived from the NMR experiments. The MS experiments generated parallel groupings, in which, for example, Group B is known as Class Ic (Lambert et al. 2008).

Resin Maturity. Resinous material is generated from trees and bushes usually as the result of damage or disease. It is sticky and often strongly redolent on formation, but usually hardens within a few days or months to a rigid solid. Such materials, referred to as modern resins, may be harvested and examined spectroscopically. Certain resins are extremely robust over time, nearly impervious to conditions of the environment. Unlike other natural organic materials, like leaves, bark, and wood, resins (particularly when buried) do not decay rapidly into soil humus. Through processes of polymerization, cross-linking, and oxidation, the original di- and triterpenes become a massively interlinked molecular mass that resembles a rock (Lambert et al. 2008). Such processes require geological times, most typically cited as millions of years (Schlee and Glöckner 1978) but as little as 40,000 years (Vávra 2009). In this work, we refer to such materials as fossilized resin or amber, although other terms also are used. Such materials are said to be highly matured, although the process of maturation is nonlinear and ongoing. Thus amber from the Triassic or Carboniferous periods exhibits higher maturity than amber from Cretaceous or earlier periods. Resin with levels of maturity intermediate between amber and modern materials often is observed, with ages as low as a few hundred years to as high as nearly a million years. We call such materials semi-fossilized resins or copal herein, although alternative names are used.

Langenheim (2003) has pointed out the difficulty of distinguishing amber from copal by visual examination. Some sort of chemical or physical characterization must be carried out. We have found that differing levels of maturity give predictable NMR patterns. It is important to be able to make such distinctions by spectroscopic means. Whereas the robust character of fossilized 
resins makes them very attractive for use as jewelry or other decorative objects, the softer copals are not good candidates for such products, although they are seen on the market. On the other hand, copals, like modern resins, serve admirably as incense, medicinal products, and additives to food products. In our investigation of resinous materials from the Caribbean Basin and surrounding regions, we are able to distinguish between fossilized and semi-fossilized resins.

\section{Methods}

Four types of NMR spectra were taken for each sample. The ${ }^{13} \mathrm{C}$ (carbon13) nuclei were examined with complete decoupling from all surrounding hydrogen atoms, and with interrupted decoupling, a process called dipolar dephasing. The two decoupling techniques are used to generate different patterns that can be used to characterize the resins. The ${ }^{1} \mathrm{H}$ (hydrogen or proton) nuclei were examined to produce standard one-dimensional spectra that separate nuclei according to their chemical shifts, which are determined by the electronic environment of the examined nucleus. In addition, the two-dimensional method called COSY, short for COrrelation SpectroscopY, examines interactions between hydrogen atoms, the so-called coupling constant, through a spectrum with two chemical shift axes. Again, these experiments are used for pattern recognition of spectral differences. The NMR approach therefore is phenomenological in that we are examining spectral patterns rather than identifying specific molecular components, as in the MS approach. The use of four different spectral methods provides cross checks for all our conclusions.

The study set comprises 92 samples, some of which proved not to be resinous. This number includes 18 samples of modern resins from the leguminous genus Hymenaea of the Fabaceae, which is the consensus source of fossilized resin labeled Group D. The materials are described in Table 1. The map in Figure 2 provides a geographical perspective for the project.

Table 1. Sources of amber from the Caribbean and surrounding regions.

\begin{tabular}{|l|l|l|l|}
\hline $\begin{array}{l}\text { Sample } \\
\text { Number }\end{array}$ & Region $^{\mathbf{a}}$ & Source $^{\mathbf{b}}$ & Provider \\
\hline 772 & $\begin{array}{l}\text { Gulf coastal } \\
\text { United States }\end{array}$ & Llano Co., Texas & $\begin{array}{l}\text { National Museum of Natural } \\
\text { History, Washington, District } \\
\text { of Columbia, USA }\end{array}$ \\
\hline 1265 & $\begin{array}{l}\text { Gulf coastal } \\
\text { United States }\end{array}$ & Grayson Co, Texas & $\begin{array}{l}\text { Alton Brown, Richardson, } \\
\text { Texas, USA }\end{array}$ \\
\hline 335 & $\begin{array}{l}\text { Gulf coastal } \\
\text { United States }\end{array}$ & $\begin{array}{l}\text { Tishomingo Co, } \\
\text { Mississippi }\end{array}$ & $\begin{array}{l}\text { Ernest Russell, Starkville, } \\
\text { Mississippi, USA }\end{array}$ \\
\hline 63 & Modern resin & Hymenaea sp. & $\begin{array}{l}\text { G. O. Poinar, Jr., Corvallis, } \\
\text { Oregon, USA }\end{array}$ \\
\hline 164 & Modern resin & Hymenaea sp. & $\begin{array}{l}\text { G. O. Poinar, Jr., Corvallis, } \\
\text { Oregon, USA }\end{array}$ \\
\hline
\end{tabular}




\begin{tabular}{|c|c|c|c|}
\hline 473 & Modern resin & Hymenaea courbaril & $\begin{array}{l}\text { National Tropical Botanical } \\
\text { Garden, Kalaheo, Kauai, } \\
\text { Hawai'i, USA }\end{array}$ \\
\hline 520 & Modern resin & Hymenaea sp. & $\begin{array}{l}\text { G. O. Poinar, Jr., Corvallis, } \\
\text { Oregon, USA }\end{array}$ \\
\hline 541 & Modern resin & Hymenaea sp. & $\begin{array}{l}\text { Field Museum, Chicago, } \\
\text { Illinois, USA }\end{array}$ \\
\hline 569 & Modern resin & Hymenaea verrucosa & $\begin{array}{l}\text { Field Museum, Chicago, } \\
\text { Illinois, USA }\end{array}$ \\
\hline 578 & Modern resin & Hymenaea verrucosa & $\begin{array}{l}\text { Jorge A. Santiago-Blay, US } \\
\text { National Arboretum, } \\
\text { Washington, District of } \\
\text { Columbia, USA }\end{array}$ \\
\hline 635 & Modern resin & Hymenaea verrucosa & $\begin{array}{l}\text { New York Botanical Garden, } \\
\text { Bronx, New York, USA }\end{array}$ \\
\hline 645 & Modern resin & $\begin{array}{l}\text { Hymenaea } \\
\text { stignocarpa }\end{array}$ & $\begin{array}{l}\text { New York Botanical Garden, } \\
\text { Bronx, New York, USA }\end{array}$ \\
\hline 647 & Modern resin & Hymenaea intermedia & $\begin{array}{l}\text { New York Botanical Garden, } \\
\text { Bronx, New York, USA }\end{array}$ \\
\hline 648 & Modern resin & Hymenaea martiana & $\begin{array}{l}\text { New York Botanical Garden, } \\
\text { Bronx, New York, USA }\end{array}$ \\
\hline 651 & Modern resin & Hymenaea rubriflora & $\begin{array}{l}\text { New York Botanical Garden, } \\
\text { Bronx, New York, USA }\end{array}$ \\
\hline 652 & Modern resin & Hymenaea aurea & $\begin{array}{l}\text { New York Botanical Garden, } \\
\text { Bronx, New York, USA }\end{array}$ \\
\hline 653 & Modern resin & $\begin{array}{l}\text { Hymenaea } \\
\text { oblongifolia }\end{array}$ & $\begin{array}{l}\text { New York Botanical Garden, } \\
\text { Bronx, New York, USA }\end{array}$ \\
\hline 654 & Modern resin & Hymenaea velutina & $\begin{array}{l}\text { New York Botanical Garden, } \\
\text { Bronx, New York, USA }\end{array}$ \\
\hline 655 & Modern resin & Hymenaea reticulata & $\begin{array}{l}\text { New York Botanical Garden, } \\
\text { Bronx, New York, USA }\end{array}$ \\
\hline 656 & Modern resin & Hymenaea courbaril & $\begin{array}{l}\text { New York Botanical Garden, } \\
\text { Bronx, New York, USA }\end{array}$ \\
\hline 657 & Modern resin & Hymenaea courbaril & $\begin{array}{l}\text { New York Botanical Garden, } \\
\text { Bronx, New York, USA }\end{array}$ \\
\hline $1364^{c}$ & Puerto Rico & $\begin{array}{l}\text { Punta Candelero site, } \\
\text { Humacao }\end{array}$ & $\begin{array}{l}\text { Miguel Rodríguez López, } \\
\text { Universidad del Turabo, Puerto } \\
\text { Rico }\end{array}$ \\
\hline 1472 & Puerto Rico & Bayamón & $\begin{array}{l}\text { Eugene Hartstein, formerly } \\
\text { Bayamón, Puerto Rico }\end{array}$ \\
\hline 1515 & $\begin{array}{l}\text { Puerto Rico } \\
\text { or Dominican } \\
\text { Republic } \\
\end{array}$ & unprovenanced & $\begin{array}{l}\text { Mónica Morayma Solórzano, } \\
\text { Frankfurt-am-Main, Germany }\end{array}$ \\
\hline 61 & $\begin{array}{l}\text { Dominican } \\
\text { Republic }\end{array}$ & unprovenanced & $\begin{array}{l}\text { G. O. Poinar, Jr., Corvallis, } \\
\text { Oregon, USA }\end{array}$ \\
\hline 64 & $\begin{array}{l}\text { Dominican } \\
\text { Republic }\end{array}$ & Tamburil & $\begin{array}{l}\text { G. O. Poinar, Jr., Corvallis, } \\
\text { Oregon, USA }\end{array}$ \\
\hline
\end{tabular}




\begin{tabular}{|c|c|c|c|}
\hline 65 & $\begin{array}{l}\text { Dominican } \\
\text { Republic }\end{array}$ & La Toca & $\begin{array}{l}\text { G. O. Poinar, Jr., Corvallis, } \\
\text { Oregon, USA }\end{array}$ \\
\hline 66 & $\begin{array}{l}\text { Dominican } \\
\text { Republic }\end{array}$ & La Aguita & $\begin{array}{l}\text { G. O. Poinar, Jr., Corvallis, } \\
\text { Oregon, USA }\end{array}$ \\
\hline 67 & $\begin{array}{l}\text { Dominican } \\
\text { Republic }\end{array}$ & Palo Alto & $\begin{array}{l}\text { G. O. Poinar, Jr., Corvallis, } \\
\text { Oregon, USA }\end{array}$ \\
\hline 68 & $\begin{array}{l}\text { Dominican } \\
\text { Republic }\end{array}$ & El Valle & $\begin{array}{l}\text { G. O. Poinar, Jr., Corvallis, } \\
\text { Oregon, USA }\end{array}$ \\
\hline 69 & $\begin{array}{l}\text { Dominican } \\
\text { Republic }\end{array}$ & Bayaguana & $\begin{array}{l}\text { G. O. Poinar, Jr., Corvallis, } \\
\text { Oregon, USA }\end{array}$ \\
\hline 70 & $\begin{array}{l}\text { Dominican } \\
\text { Republic }\end{array}$ & Cotuí & $\begin{array}{l}\text { G. O. Poinar, Jr., Corvallis, } \\
\text { Oregon, USA }\end{array}$ \\
\hline 435 & $\begin{array}{l}\text { Dominican } \\
\text { Republic }\end{array}$ & unprovenanced & Perkovsky, Ukraine \\
\hline 514 & $\begin{array}{l}\text { Dominican } \\
\text { Republic } \\
\end{array}$ & unprovenanced & $\begin{array}{l}\text { František Kovařik, Prague, } \\
\text { Czech Republic }\end{array}$ \\
\hline 1473 & $\begin{array}{l}\text { Dominican } \\
\text { Republic }\end{array}$ & unprovenanced & $\begin{array}{l}\text { Patrick Craig, Guerneville, } \\
\text { California, USA }\end{array}$ \\
\hline 62 & Mexico & unprovenanced & $\begin{array}{l}\text { G. O. Poinar, Jr., Corvallis, } \\
\text { Oregon, USA }\end{array}$ \\
\hline 73 & Mexico & Totolapa, Chiapas & $\begin{array}{l}\text { G. O. Poinar, Jr., Corvallis, } \\
\text { Oregon, USA }\end{array}$ \\
\hline 74 & Mexico & Totolapa, Chiapas & $\begin{array}{l}\text { G. O. Poinar, Jr., Corvallis, } \\
\text { Oregon, USA }\end{array}$ \\
\hline 75 & Mexico & Simojovel, Chiapas & $\begin{array}{l}\text { G. O. Poinar, Jr., Corvallis, } \\
\text { Oregon, USA }\end{array}$ \\
\hline 76 & Mexico & Simojovel, Chiapas & $\begin{array}{l}\text { G. O. Poinar, Jr., Corvallis, } \\
\text { Oregon, USA }\end{array}$ \\
\hline 82 & Mexico & Simojovel, Chiapas & $\begin{array}{l}\text { G. O. Poinar, Jr., Corvallis, } \\
\text { Oregon, USA }\end{array}$ \\
\hline 83 & Mexico & Simojovel, Chiapas & $\begin{array}{l}\text { G. O. Poinar, Jr., Corvallis, } \\
\text { Oregon, USA }\end{array}$ \\
\hline 92 & Mexico & Simojovel, Chiapas & $\begin{array}{l}\text { G. O. Poinar, Jr., Corvallis, } \\
\text { Oregon, USA }\end{array}$ \\
\hline 93 & Mexico & Simojovel, Chiapas & $\begin{array}{l}\text { G. O. Poinar, Jr., Corvallis, } \\
\text { Oregon, USA }\end{array}$ \\
\hline 94 & Mexico & Simojovel, Chiapas & $\begin{array}{l}\text { G. O. Poinar, Jr., Corvallis, } \\
\text { Oregon, USA }\end{array}$ \\
\hline 95 & Mexico & Simojovel, Chiapas & $\begin{array}{l}\text { G. O. Poinar, Jr., Corvallis, } \\
\text { Oregon, USA }\end{array}$ \\
\hline 96 & Mexico & Simojovel, Chiapas & $\begin{array}{l}\text { G. O. Poinar, Jr., Corvallis, } \\
\text { Oregon, USA }\end{array}$ \\
\hline 158 & Mexico & Totolapa, Chiapas & $\begin{array}{l}\text { G. O. Poinar, Jr., Corvallis, } \\
\text { Oregon, USA }\end{array}$ \\
\hline 159 & Mexico & Totolapa, Chiapas & $\begin{array}{l}\text { G. O. Poinar, Jr., Corvallis, } \\
\text { Oregon, USA }\end{array}$ \\
\hline
\end{tabular}




\begin{tabular}{|c|c|c|c|}
\hline 160 & Mexico & Totolapa, Chiapas & $\begin{array}{l}\text { G. O. Poinar, Jr., Corvallis, } \\
\text { Oregon, USA }\end{array}$ \\
\hline 161 & Mexico & Simojovel, Chiapas & $\begin{array}{l}\text { G. O. Poinar, Jr., Corvallis, } \\
\text { Oregon, USA }\end{array}$ \\
\hline 162 & Mexico & Chapayal, Chiapas & $\begin{array}{l}\text { G. O. Poinar, Jr., Corvallis, } \\
\text { Oregon, USA }\end{array}$ \\
\hline 163 & Mexico & $\begin{array}{l}\text { Ocozocuantla de } \\
\text { Espinosa (Mal Paso), } \\
\text { Chiapas }\end{array}$ & $\begin{array}{l}\text { G. O. Poinar, Jr., Corvallis, } \\
\text { Oregon, USA }\end{array}$ \\
\hline 255 & Mexico & $\begin{array}{l}\text { unprovenanced } \\
\text { Chiapas }\end{array}$ & $\begin{array}{l}\text { G. O. Poinar, Jr., Corvallis, } \\
\text { Oregon, USA }\end{array}$ \\
\hline 898 & Mexico & $\begin{array}{l}\text { Pueblo Nuevo } \\
\text { Solistahuacán, Chiapas }\end{array}$ & $\begin{array}{l}\text { New York Botanical Garden, } \\
\text { Bronx, New York, USA }\end{array}$ \\
\hline 1448 & Mexico & unprovenanced & $\begin{array}{l}\text { National Museum of American } \\
\text { History, Washington, District } \\
\text { of Columbia, USA }\end{array}$ \\
\hline 1475 & Mexico & Palenque, Chiapas & Alex Brown, Oregon, USA \\
\hline 119 & $\begin{array}{l}\text { Central } \\
\text { America }\end{array}$ & unprovenanced Belize & $\begin{array}{l}\text { G. O. Poinar, Jr., Corvallis, } \\
\text { Oregon, USA }\end{array}$ \\
\hline 1034 & $\begin{array}{l}\text { Central } \\
\text { America }\end{array}$ & $\begin{array}{l}\text { San Andrés, El } \\
\text { Salvador }\end{array}$ & $\begin{array}{l}\text { National Museum of Natural } \\
\text { History, Washington, District } \\
\text { of Columbia, USA }\end{array}$ \\
\hline 1035 & $\begin{array}{l}\text { Central } \\
\text { America }\end{array}$ & San José, Costa Rica & $\begin{array}{l}\text { National Museum of Natural } \\
\text { History, Washington, District } \\
\text { of Columbia, USA }\end{array}$ \\
\hline 1541 & $\begin{array}{l}\text { Central } \\
\text { America } \\
\end{array}$ & $\begin{array}{l}\text { unprovenanced Costa } \\
\text { Rica }\end{array}$ & Teruhisa Ueno, Fukuoka, Japan \\
\hline 173 & Colombia & unprovenanced & $\begin{array}{l}\text { G. O. Poinar, Jr., Corvallis, } \\
\text { Oregon, USA }\end{array}$ \\
\hline 174 & Colombia & unprovenanced & $\begin{array}{l}\text { G. O. Poinar, Jr., Corvallis, } \\
\text { Oregon, USA }\end{array}$ \\
\hline 183 & Colombia & unprovenanced & $\begin{array}{l}\text { G. O. Poinar, Jr., Corvallis, } \\
\text { Oregon, USA }\end{array}$ \\
\hline 766 & Colombia & $\begin{array}{l}\text { Bucaramanga, } \\
\text { Santander }\end{array}$ & $\begin{array}{l}\text { National Museum of Natural } \\
\text { History, Washington, District } \\
\text { of Columbia, USA }\end{array}$ \\
\hline 767 & Colombia & Medellín, Antioquia & $\begin{array}{l}\text { National Museum of Natural } \\
\text { History, Washington, District } \\
\text { of Columbia, USA }\end{array}$ \\
\hline 950 & Colombia & $\begin{array}{l}\text { unprovenanced } \\
\text { Santander }\end{array}$ & $\begin{array}{l}\text { R. S. Dietz, Tucson, Arizona, } \\
\text { USA }\end{array}$ \\
\hline 1470 & Colombia & unprovenanced & OMI, Inc. \\
\hline 1471 & Colombia & unprovenanced & OMI, Inc. \\
\hline 1512 & Colombia & $\begin{array}{l}\text { El Cerrejón Norte, La } \\
\text { Guajira }\end{array}$ & $\begin{array}{l}\text { National Museum of American } \\
\text { History, Washington, District } \\
\text { of Columbia, USA }\end{array}$ \\
\hline
\end{tabular}




\begin{tabular}{|c|c|c|c|}
\hline 1516 & Colombia & unprovenanced & $\begin{array}{l}\text { Mónica Morayma Solórzano, } \\
\text { Frankfurt am Main, Germany }\end{array}$ \\
\hline 1517 & Colombia & unprovenanced & $\begin{array}{l}\text { Mónica Morayma Solórzano, } \\
\text { Frankfurt am Main, Germany }\end{array}$ \\
\hline $1522^{c}$ & Colombia & $\begin{array}{l}\text { Nahuange site, Santa } \\
\text { Marta, Magdalena }\end{array}$ & $\begin{array}{l}\text { Alan Francisco, Field Museum, } \\
\text { Chicago, Illinois, USA }\end{array}$ \\
\hline $1523^{c}$ & Columbia & $\begin{array}{l}\text { Nahuange site, Santa } \\
\text { Marta, Magdalena }\end{array}$ & $\begin{array}{l}\text { Alan Francisco, Field Museum, } \\
\text { Chicago, Illinois, USA }\end{array}$ \\
\hline $1524^{c}$ & Columbia & $\begin{array}{l}\text { Nahuange site, Santa } \\
\text { Marta, Magdalena }\end{array}$ & $\begin{array}{l}\text { Alan Francisco, Field Museum, } \\
\text { Chicago, Illinois, USA }\end{array}$ \\
\hline $1525^{c}$ & Columbia & $\begin{array}{l}\text { Nahuange site, Santa } \\
\text { Marta, Magdalena }\end{array}$ & $\begin{array}{l}\text { Alan Francisco, Field Museum, } \\
\text { Chicago, Illinois, USA }\end{array}$ \\
\hline 246 & $\begin{array}{l}\text { Other South } \\
\text { American }\end{array}$ & $\begin{array}{l}\text { unprovenanced } \\
\text { Guyana }\end{array}$ & $\begin{array}{l}\text { G. O. Poinar, Jr., Corvallis, } \\
\text { Oregon, USA }\end{array}$ \\
\hline 249 & $\begin{array}{l}\text { Other South } \\
\text { American }\end{array}$ & $\begin{array}{l}\text { unprovenanced } \\
\text { Uruguay }\end{array}$ & $\begin{array}{l}\text { G. O. Poinar, Jr., Corvallis, } \\
\text { Oregon, USA }\end{array}$ \\
\hline 1427 & $\begin{array}{l}\text { Other South } \\
\text { American }\end{array}$ & $\begin{array}{l}\text { unprovenanced } \\
\text { Uruguay }\end{array}$ & $\begin{array}{l}\text { Patrick Craig, Guermeville, } \\
\text { CA, USA }\end{array}$ \\
\hline 251 & $\begin{array}{l}\text { Other South } \\
\text { American }\end{array}$ & Mato Grosso, Brazil & $\begin{array}{l}\text { G. O. Poinar, Jr., Corvallis, } \\
\text { Oregon, USA }\end{array}$ \\
\hline 921 & $\begin{array}{l}\text { Other South } \\
\text { American }\end{array}$ & Mato Grosso, Brazil & $\begin{array}{l}\text { Harvard University Farlow } \\
\text { Herbarium, Cambridge, MA, } \\
\text { USA }\end{array}$ \\
\hline 984 & $\begin{array}{l}\text { Other South } \\
\text { American }\end{array}$ & unprovenanced Brazil & $\begin{array}{l}\text { University Farlow Herbarium, } \\
\text { Cambridge, MA, USA }\end{array}$ \\
\hline 1426 & $\begin{array}{l}\text { Other South } \\
\text { American }\end{array}$ & Mato Grosso, Brazil & $\begin{array}{l}\text { Patrick Craig, Guerneville, } \\
\text { CA, USA }\end{array}$ \\
\hline 1514 & $\begin{array}{l}\text { Other South } \\
\text { American }\end{array}$ & Amazon, Brazil & $\begin{array}{l}\text { Rolf Simonsen, Hvidovre } \\
\text { Denmark }\end{array}$ \\
\hline 521 & $\begin{array}{l}\text { Other South } \\
\text { American }\end{array}$ & unprovenanced & $\begin{array}{l}\text { G. O. Poinar, Jr., Corvallis, } \\
\text { Oregon, USA }\end{array}$ \\
\hline 522 & $\begin{array}{l}\text { Other South } \\
\text { American }\end{array}$ & unprovenanced & $\begin{array}{l}\text { G. O. Poinar, Jr., Corvallis, } \\
\text { Oregon, USA }\end{array}$ \\
\hline 765 & $\begin{array}{l}\text { Other South } \\
\text { American }\end{array}$ & Guayaquil, Ecuador & $\begin{array}{l}\text { National Museum of Natural } \\
\text { History, Washington, District } \\
\text { of Columbia, USA }\end{array}$ \\
\hline 896 & $\begin{array}{l}\text { Other South } \\
\text { American }\end{array}$ & $\begin{array}{l}\text { Urumaco formation, } \\
\text { Falcón, Venezuela }\end{array}$ & $\begin{array}{l}\text { Daniel Fisher, New York } \\
\text { Botanical Garden, Bronx, New } \\
\text { York, USA }\end{array}$ \\
\hline 922 & $\begin{array}{l}\text { Other South } \\
\text { American }\end{array}$ & $\begin{array}{l}\text { unprovenanced } \\
\text { Venezuela }\end{array}$ & $\begin{array}{l}\text { Harvard University Farlow } \\
\text { Herbarium, Cambridge, } \\
\text { Massachusetts, USA }\end{array}$ \\
\hline 1456 & $\begin{array}{l}\text { Other South } \\
\text { American }\end{array}$ & $\begin{array}{l}\text { Barquisimeto, Lara, } \\
\text { Venezuela }\end{array}$ & $\begin{array}{l}\text { Royal Mapes, Athens, Ohio, } \\
\text { USA }\end{array}$ \\
\hline 1488 & $\begin{array}{l}\text { Other South } \\
\text { American }\end{array}$ & unprovenanced Perú & $\begin{array}{l}\text { Laboratory of Tree-Ring } \\
\text { Research, University of } \\
\text { Arizona, Tucson, Arizona, USA }\end{array}$ \\
\hline
\end{tabular}




\begin{tabular}{|l|l|l|l|}
\hline 1585 & $\begin{array}{l}\text { Other South } \\
\text { American }\end{array}$ & Iquitos, Loreto, Perú & $\begin{array}{l}\text { Pierre-Olivier Antoine, } \\
\text { Montpellier, France }\end{array}$ \\
\hline
\end{tabular}

${ }^{a}$ This column indicates the overall region from which the materials, either amber or copal, were found. The name also corresponds to the appropriate section in the discussion. The classification is irrelevant for modern resins.

${ }^{\mathrm{b}}$ For amber or copal, the source of the discovered material is given. For modern resins, the genus and species are given.

${ }^{c}$ Archaeological specimen.

\section{Gulf Coastal United States}

The American Gulf Coast extends from Texas across the American Southeast to Florida. Samples from other parts of the United States, from California to the East Coast, have proved to be Group A for the most part and occasionally Group B (Lambert et al. 2008). We have analyzed two previously unreported samples from the state of Texas (TX) and one from Mississippi (MS). Sample 772 from Llano Co., squarely in the center of Texas, is clearly from Group A. Sample 1265 from Grayson Co., on the border of Texas with Oklahoma, also exhibits the Group A pattern. Texas is in the south central part of the United States and has an extensive Gulf Coast. Mississippi in the southeast United States has a short Gulf coastline. Sample 335 from Tishomingo Co., at the northeastern tip of this state, also is clearly from Group A, with the classic carbon patterns. The proton pattern is similar to that of the Texas sample from Grayson Co.

The saturated region of Group A spectra $(\delta 0-40)$ such as these has the dominant peak at $\delta 38$ and a medium peak at $\delta 18$ (Figure 3). The dominant peak has several shoulders and small peaks on its left, between $\delta 40$ and 56 . The unsaturated region ( $\delta 110-160)$ has no peaks for exomethylene groups at $\delta 110$ and 150 but has weak peaks for internal (di- and tri-substituted) double bonds at $\delta 120-140$. There sometimes is a small carbonyl peak in the spectrum at $\delta 180$. With dipolar dephasing, the saturated region of both samples is sharper but weaker, with the dominant peak still at $\delta 38$ and three or four other significant peaks between $\delta 14$ and 40 . The unsaturated region is very weak. The carbonyl peak at $\delta 180$, if present, usually survives. In the proton spectra (Figure 4), the three characteristic Group A saturated groupings $(\delta 0-3)$ are present (Lambert et al. 2012), centered at $\delta 1.8$ (broad with multiple peaks), 1.2 (narrow multiplet), and 1.6 (broad with two main peaks), although the middle grouping is more intense than the two broad groupings on either side. The peaks in the unsaturated region $(\delta 3.0-5.5)$ are weaker than other Group A counterparts. The COSY spectra contain few diagnostic peaks. 


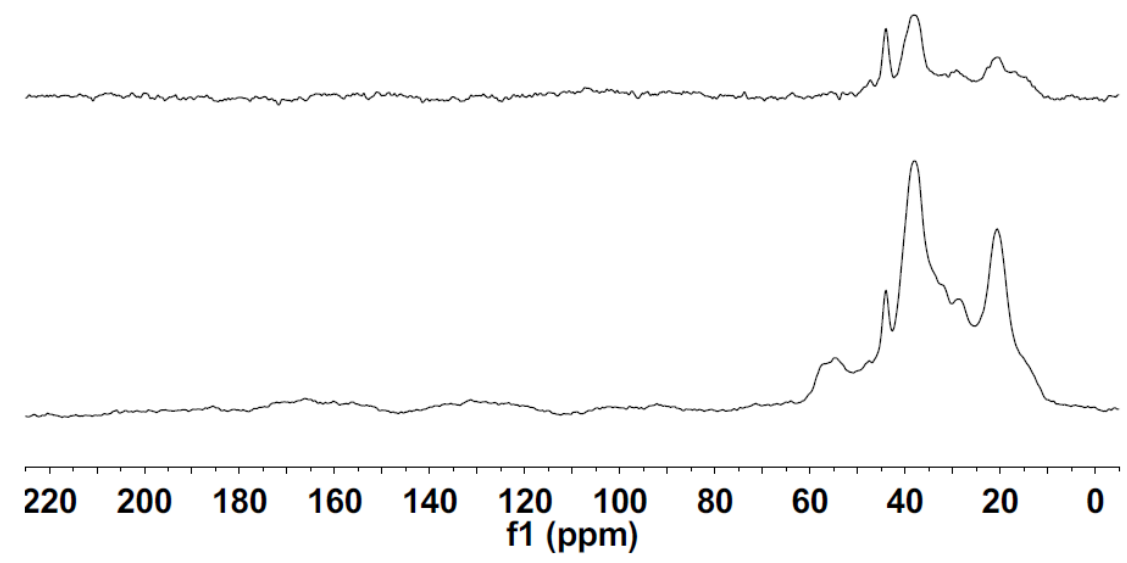

Figure 3. The $75.4 \mathrm{MHz}{ }^{13} \mathrm{C}$ NMR spectrum (lower) with complete decoupling and (upper) with dipolar dephasing of sample no. 335 from the McShan Formation on the Tombigbee Waterway, Tishomingo Co., MS, Santonian period, 83-86 Ma.

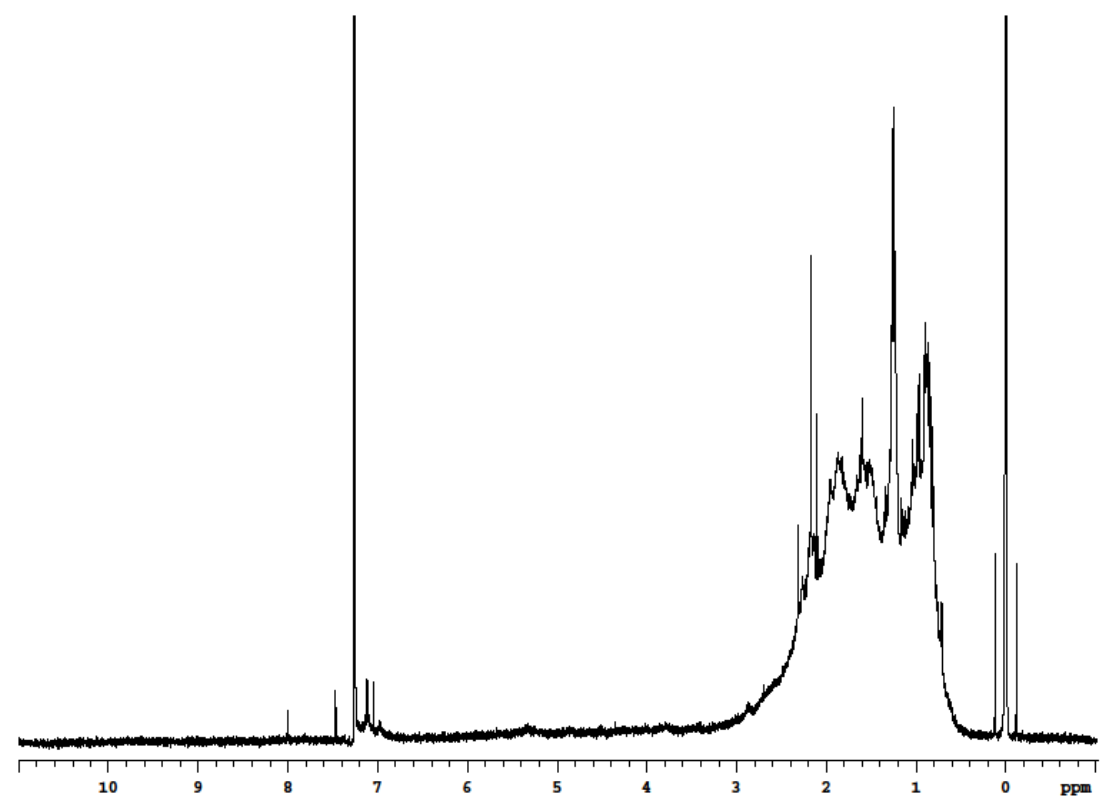

Figure 4. The $500 \mathrm{MHz}{ }^{1} \mathrm{H}$ spectrum in $\mathrm{CHCl}_{3}$ of sample no. 335 from Tishomingo Co., Mississippi. USA. 


\section{Resins from the Hymenaea and Related Genera}

Group A is the dominant type of North American amber from the Gulf shores of the United States through Canada to Alaska, with a few Group B exceptions, and there have never been any observed cases of Group D amber north of southern Mexico. Group D amber has been associated, through plant parts extracted from the body of the amber, with the species Hymenaea courbaril in the Caribbean and H. verrucosa in East Africa (Langenheim 2003). Consequently, we have surveyed a variety of resins from the genus Hymenaea and from related genera. We have found that resins from the leguminous genera Caesalpinia, Copaifera, Daniellia, and Guibourtia produce the same spectral pattern as Hymenaea. All these genera are from the Fabaceae, subfamily Caesalpinioidea, tribe Detarieae (Lambert et al. 2009). We surveyed these materials to provide general comparisons with semi-fossilized and fossilized resins found not only in the Americas but also in Africa.
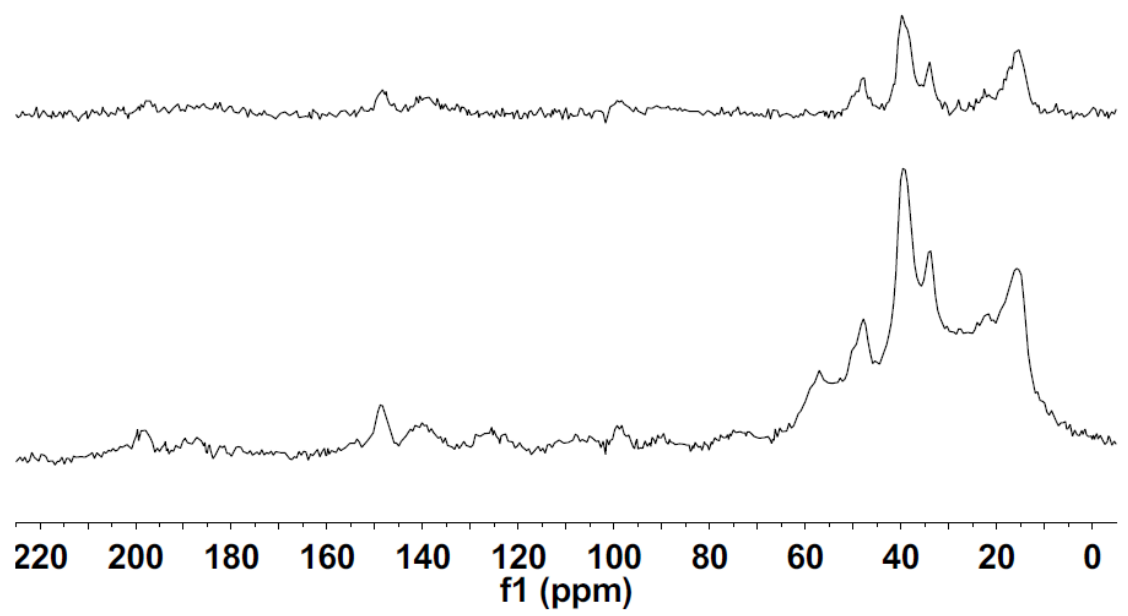

Figure 5. The $75.4 \mathrm{MHz}{ }^{13} \mathrm{C}$ NMR spectrum (lower) with complete decoupling and (upper) with dipolar dephasing of sample no.520, Hymenaea courbaril from Brazil.

The carbon spectrum of $H$. courbaril has numerous peaks in both the saturated and unsaturated regions (Figure 5, above). The dominant saturated peak is at $\delta 39$, with medium peaks at $\delta 16$ (broad) and 49 . The unsaturated region has weak peaks from internal carbons at $\delta 125-140$, one from the quaternary exomethylene carbon $\left(>\mathbf{C}==\mathrm{CH}_{2}\right)$ at $\delta 149$, and a weak peak from the unsubstituted exomethylene carbon $\left(>\mathrm{C}==\mathrm{CH}_{2}\right)$ at $\delta 108$. The carbonyl region has small peaks at $\delta 187$ and 198 . The spectrum with dipolar dephasing has three strong, peaks at $\delta 16,39$, and 49. The $1 \mathrm{D}$ proton spectrum (Figure 6) is dominated by the saturated peaks, covering the region from $\delta 0.6$ to 2.4. The 
dominant groupings are centered at $\delta 0.9$ and 1.6. There often is a characteristic pair of doublets in the electron-withdrawing (EWG) region at $\delta 3.1$ and 3.4, and there is a reliable pair of peaks in the unsaturated region at $\delta 4.5$ and 4.8. The 2D COSY spectrum has a cross peak at 3.3/3.6, which probably corresponds to the observed 1D doublet at $\delta 3.1$ and 3.4.

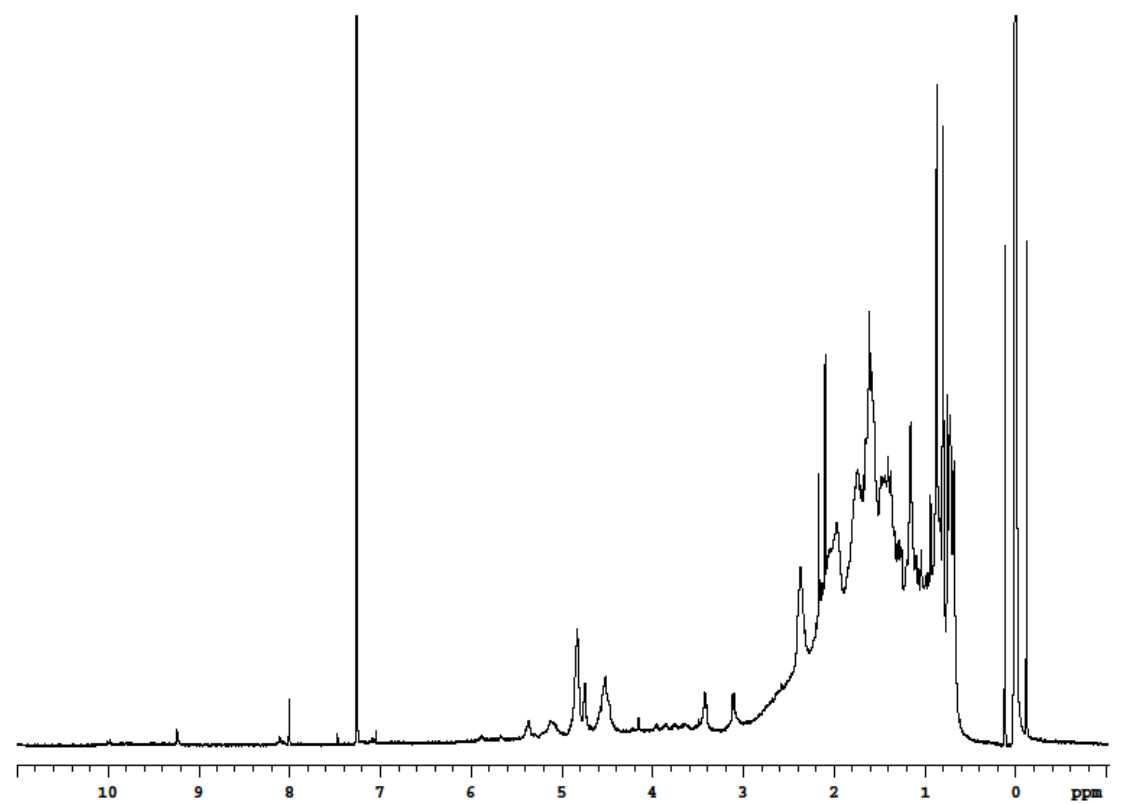

Figure 6. The $400 \mathrm{MHz}{ }^{1} \mathrm{H}$ spectrum in $\mathrm{CHCl}_{3}$ of sample no. 520, Hymenaea courbaril.

The African species, H. verrucosa, (sample 569) exhibits very similar spectra. The carbon spectrum is basically the same, both with normal decoupling and dipolar dephasing. The 1D proton spectrum differs primarily in having weaker doublets at $\delta 3.1$ and 3.4. The peaks at $\delta 4.5$ and 4.8 are present, but also several other unsaturated peaks. The COSY spectrum still has the cross peak at 3.3/3.6. Some eight other species of Hymenaea also have similar spectra, as do many species of Copaifera, Daniellia, and Guibourtia.

\section{Dominican Republic}

We examined 11 samples attributed to this country located on the Caribbean island of Hispaniola (Figure 2), four of which are unprovenanced. The provenanced seven were associated with specific mining sites at the time they were acquired (Lambert et al. 1985). Spectra of amber and copal from the Dominican Republic are very similar to those of Hymenaea and related resins, but vary because of differences in age or maturity. The strongest peaks in the 
carbon spectra, represented by the mining site La Aguita (Figure 7), always in the saturated region, are at $\delta 20$ and 39, with smaller peaks at $\delta 28,33,48$, and 57 (some of those often as shoulders). The sample from La Toca is the oldest (most highly matured) and has the strongest peaks in the unsaturated region from the internal carbons, and weaker peaks from the exomethylene carbons. The saturated and carbonyl regions are similar to the resins. The proton spectrum has only weak unsaturated peaks and no COSY cross peaks. The spectrum of the sample from Tamburil (next most highly matured) shows carbon exomethylene resonances, weak unsaturated proton peaks at $\delta 3.1,2.4,4.5$, and 4.8, and COSY cross peak at 3.3/3.6. The sample from La Aguita (Figure 7) continues this trend. It is the first sample for which we had the carbon spectrum with dipolar dephasing, which shows the characteristic three peaks at $\delta 17,38$, and 48. For La Aguita, Palo Alto, and Bayaguana, the four unsaturated peaks are well pronounced. The youngest or least matured sample is from the site of Cotuí, and its carbon spectrum exhibits the strongest exomethylene resonances, but still the same three peak spectrum with dipolar dephasing. Although the proton spectrum (Figure 8) has weak unsaturated peaks at $\delta 4.5$ and 4.8 , the peaks at $\delta 3.1$ and 3.4 are clearly visible, as is the cross peak at 3.3/3.6. Thus, the spectra of samples from the Dominican Republic closely resemble those of Hymenaea species, with some variation resulting from differences in age and maturity.
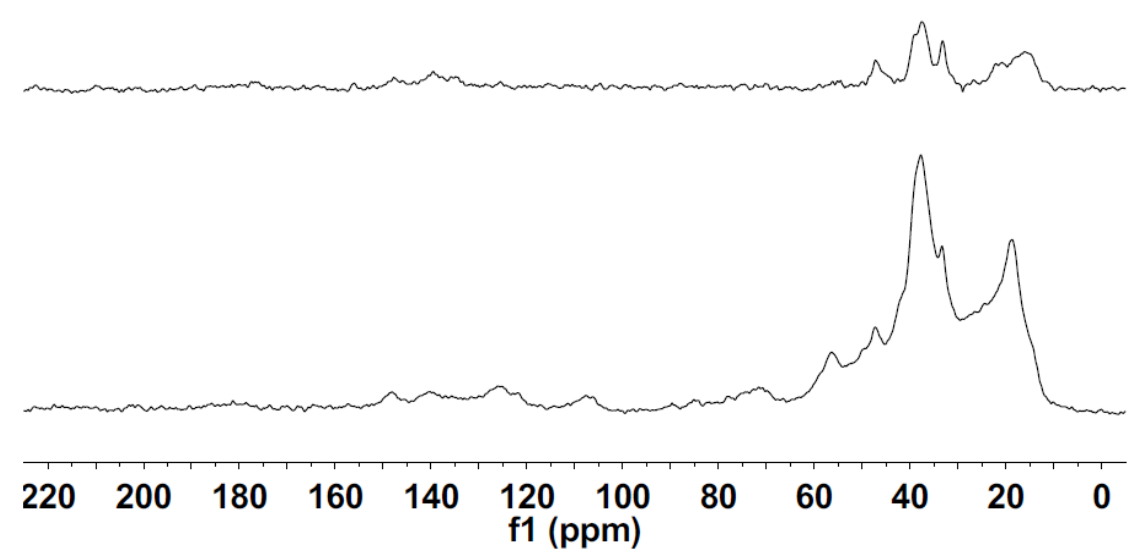

Figure 7. The $75.4 \mathrm{MHz}{ }^{13} \mathrm{C}$ NMR spectrum (lower) with complete decoupling and (upper) with dipolar dephasing of sample no. 66 from La Aguita mine, Dominican Republic. 


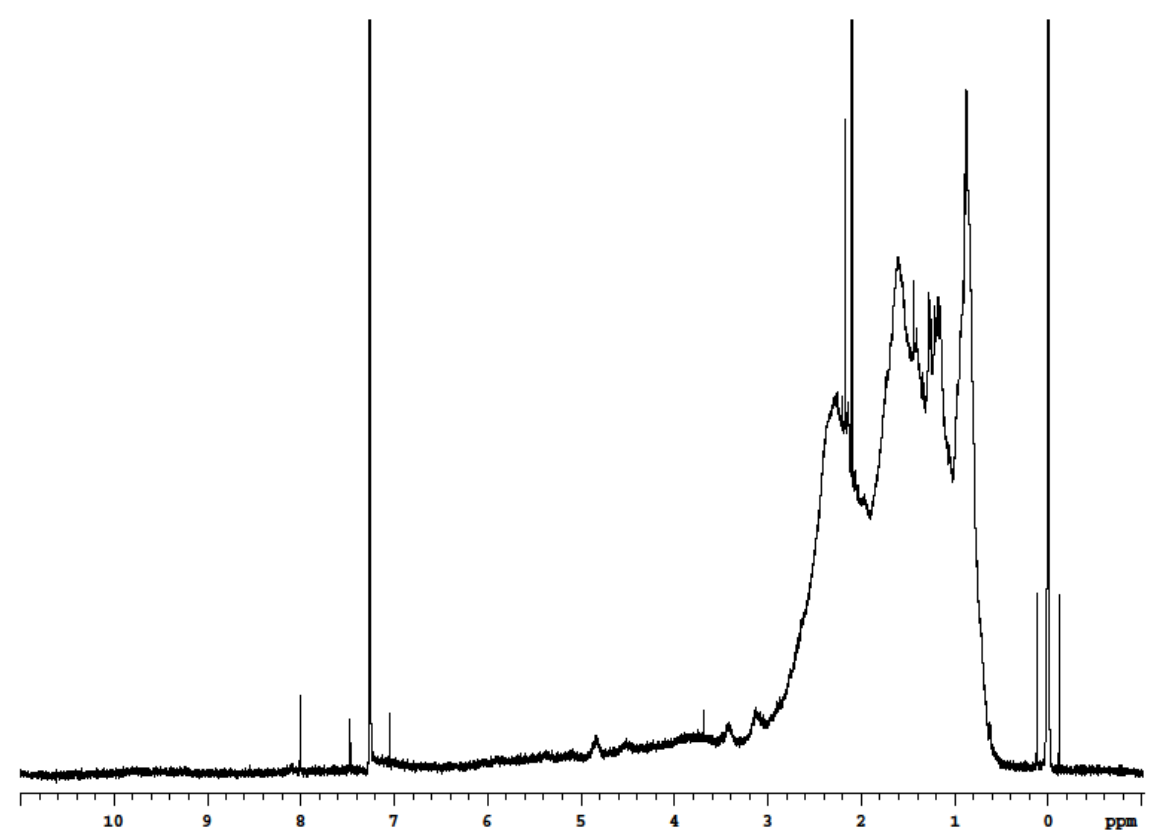

Figure 8. The $400 \mathrm{MHz}{ }^{1} \mathrm{H}$ spectrum in $\mathrm{CHCl}_{3}$ of sample no. 66 from La Aguita mine, Dominican Republic.

\section{Puerto Rico}

We have two samples from Puerto Rico, and both closely resemble the behavior of the older or more highly matured samples from the Dominican Republic. Sample 1364 was recovered from an archaeological site in Humacao on the eastern coast known as Punta Candelero. This specimen is associated with the Huecoid component of the site (Rodríguez López 1991b), in a context dated approximately between AD 200 and 500 AD. The carbon spectra of this sample resemble that from La Toca with very weak exomethylene carbon resonances, although the spectrum with dipolar dephasing retains its three-peak structure. The $1 \mathrm{D}{ }^{1} \mathrm{H}$ spectrum has peaks at $\delta 3.1$ and 3.4. Sample 1472 was obtained from an active pit in Bayamón, a city in the northern coastal valley just east of the capital of San Juan. The carbon spectrum of this sample (Figure 9) also exhibits weak exomethylene carbon peaks at $\delta 105$ and 148, similar to that of the sample from Bayaguana in the Dominican Republic. The proton spectrum (Figure 10) has stronger EWG and unsaturated peaks at $\delta 3.1,3.4,4.5$, and 4.8, and a COSY cross peak at 3.3/3.6 characteristic of materials derived from Fabaceae sources. Sample 1515 was unprovenanced, labeled from either Puerto Rico or the Dominican Republic. Its spectra are rich and sharp, closely resembling modern resins rather than amber. 


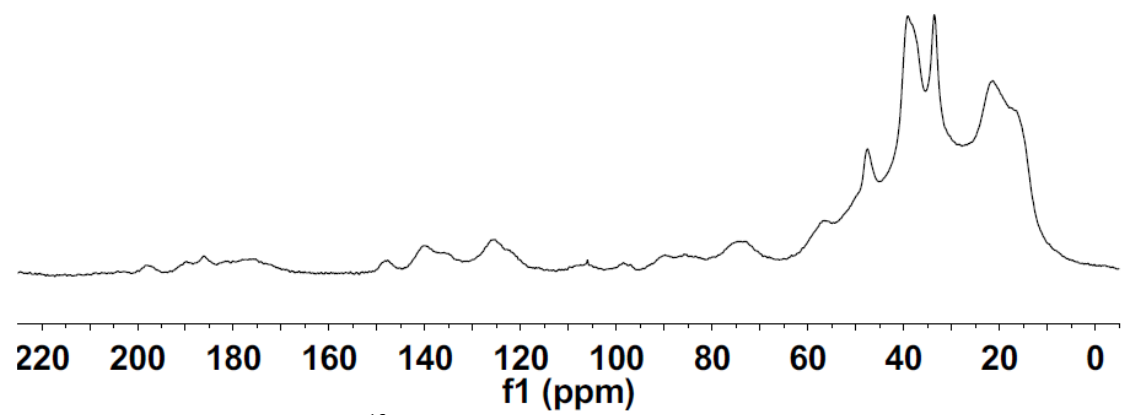

Figure 9. The $75.4 \mathrm{MHz}{ }^{13} \mathrm{C}$ NMR spectrum (lower) with complete decoupling and (upper) with dipolar dephasing of sample no. 1472, from Bayamón, Puerto Rico.

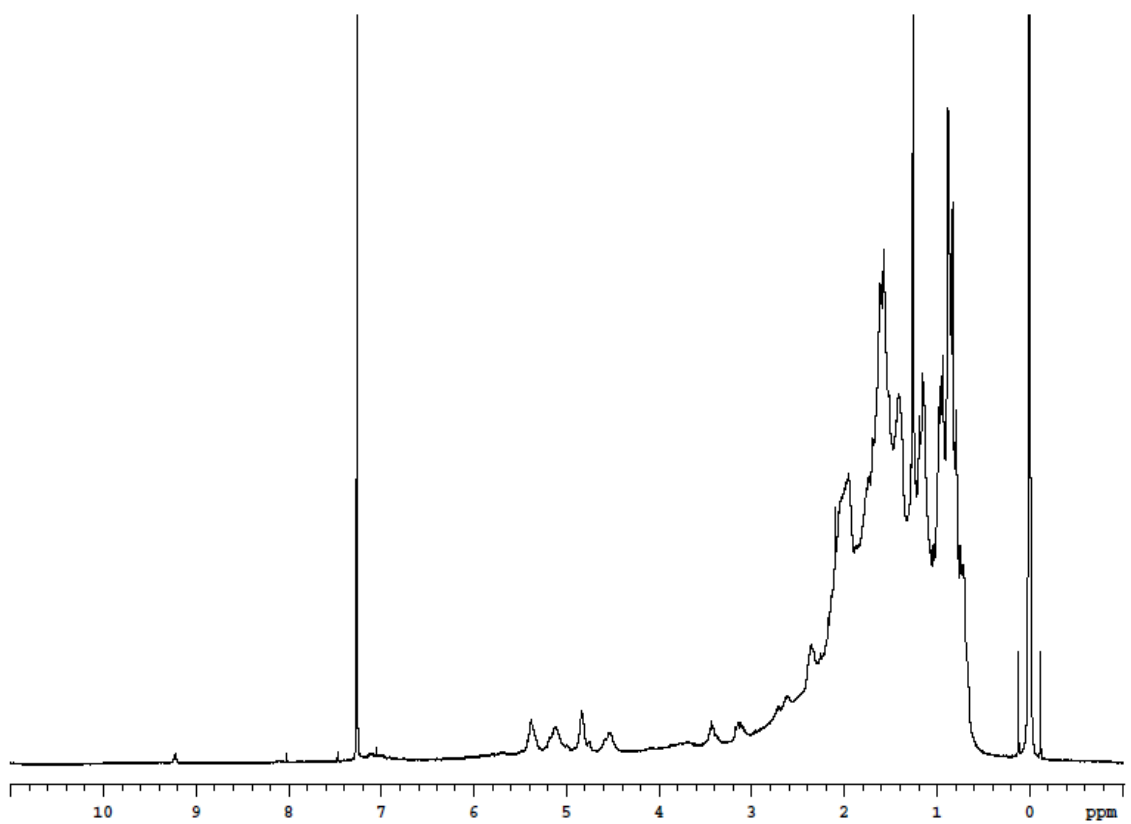

Figure 10. The $400 \mathrm{MHz}{ }^{1} \mathrm{H}$ spectrum in $\mathrm{CHCl}_{3}$ of sample no. 1472, from Bayamón, Puerto Rico. 


\section{Mexico}

Amber in Mexico is traditionally associated with the state of Chiapas, which borders on Guatemala and the Pacific Ocean in southern Mexico but is close to the Gulf of Mexico. We have 22 samples from Chiapas and two from unprovenanced sites in Mexico. Ten are from the well known site of Simojovel, and five from the equally well known site of Totolapa. In addition, we have one sample labeled only as from Chiapas, and one each from Ocozocuantla de Espinosa (actually the Confederación Nacional Campesina village of Mal Paso), Chapayal, Pueblo Nuevo Solistahuacán, and a site $12 \mathrm{~km}$ from Palenque.

The carbon spectra of the samples from Totolapa (73, 74, and 158-160) closely resemble the most highly matured samples from the Dominican Republic, in that the exomethylene resonances at $\delta 108$ and 148 are small in comparison to the peaks from internal unsaturated carbons. The dominant peaks in the saturated region are at $\delta 20$ and 39 , with smaller peaks or shoulders at $\delta$ $28,35,49$, and 57 , very similar to the Dominican spectra. The spectrum with dipolar dephasing of sample 160 has peaks at $\delta 17,20,34,38$, and 48 . In later spectra on a different instrument, the peaks at $\delta 17$ and 20 merged into a single, broad peak, as did those at $\delta 34$ and 38, to give what we call the diagnostic three peak spectrum. The proton spectrum of sample 73 has the characteristic peaks at $\delta 3.1,3.4,4.5$, and 4.8 , and the associated cross peak at 3.3/3.5. The saturated region as usual dominates the spectrum.

The carbon spectra of the samples from Simojovel $(75-96,161)$ (Figure 11) are quite similar, with even weaker exomethylene resonances. The spectra with dipolar phasing for samples 93-96 have peaks at $\delta 17$ (often a shoulder), 21, 32, 36,40 , and 47 . The proton spectra (Figure 12) usually have weak peaks $\delta 3.1$, 3.4 (with the associated cross peaks), 4.5 and 4.8. In some of the spectra the alkenic peaks are too weak to observe.
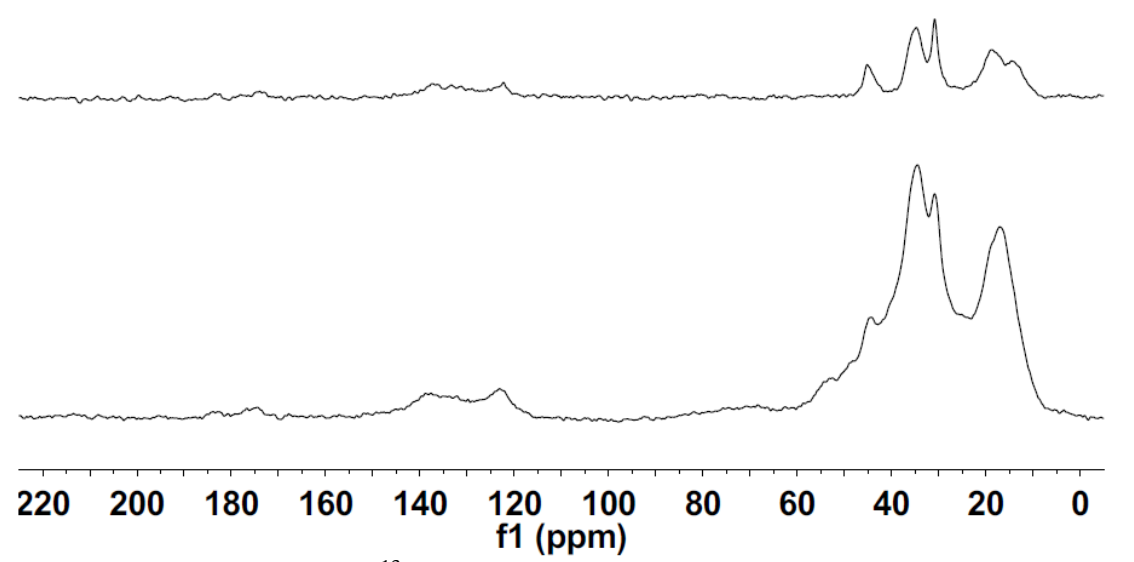

Figure 11. The $75.4 \mathrm{MHz}{ }^{13} \mathrm{C}$ NMR spectrum (lower) with complete decoupling and (upper) with dipolar dephasing of sample no. 95, from Simojovel, Chiapas, Mexico. 


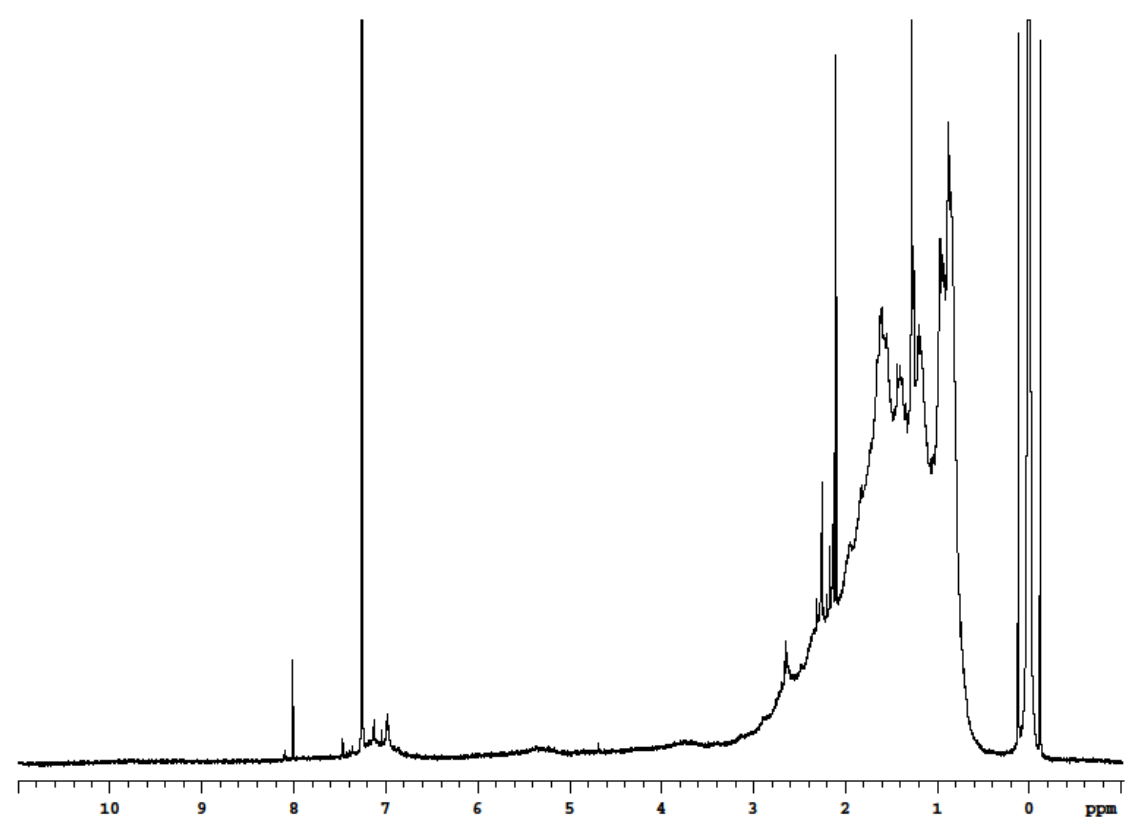

Figure 12. The $400 \mathrm{MHz}{ }^{1} \mathrm{H}$ spectrum in $\mathrm{CHCl}_{3}$ of sample no. 95, from Simojovel, Chiapas, Mexico.

The sample from Chapayal lacks exomethylene resonances but has the standard saturated region. The sample from Ocozocuantla has very strong exomethylene peaks, making us question whether it is fossilized. The sample from Solistahuacán has very weak exomethylene resonances and the standard saturated region with both regular decoupling and dipolar dephasing. In this case the proton spectrum has weak peaks at $\delta 3.1,3.4,4.5$, and 4.8 , and the associated cross peak at 3.3/3.5. The Palenque sample lacks exomethylene resonances and has the standard saturated region with both decoupling modes. The proton spectrum lacks peaks in the region $\delta$ 3.1-4.8. The unprovenanced sample 1448 gives an unusual spectrum, lacking all unsaturated resonances and with a very rich saturated regions, which indicates that the sample is not amber. The proton spectrum also bears no resemblance to the other Chiapas spectra.

The Chiapas samples clearly belong to Group D, with strong similarities with Dominican samples but suggestions of greater age or maturity. The amber sample from Puerto Rico more closely resembles samples from the Dominican Republic. The carbon spectra of the Mexican samples typically lack exomethylene resonance (Figure 11), but they are present in the Dominican and Puerto Rican samples (Figures 7 and 9). 


\section{Central America}

We have four Central American samples from three countries, all not associated with archaeological sites. Sample 119 is from Belize, but is otherwise unprovenanced. Its spectral appearance closely resembles those of Mexico and the older Dominican samples: modest exomethylene resonances, dominant resonances in the saturated region at $\delta 21$ and 39, and a small carbonyl peak at $\delta 173$. With dipolar dephasing, the carbonyl and internal alkenic resonances increase, and the saturated resonances have the usual three peak appearance (in this case, the lowest frequency resonance appears as two peaks, as is often the case with particularly good resolution). Sample 1034 from San Andrés, El Salvador, appears to be older or more highly matured. The unsaturated region contains resonances only from internal double bond carbons, and the saturated region is particularly broad. With dipolar dephasing, the saturated region contains the expected peaks at $\delta 18$ and 38, but the peak at $\delta 48$ is missing. The sample proved to be only partially soluble and did not yield an analyzable proton spectrum. Sample 1035 (Figure 13) from San José, Costa Rica, gives every indication of being a modern resin or, at most, a partially fossilized copal. Its exomethylene resonances are stronger than those of the internal carbons, and the saturated region has the broadest, richest set of spectra sometimes found in modern Hymenaea samples. The spectrum with dipolar dephasing has the two diagnostic peaks at $\delta 17$ and 40 but lacks the peak at $\delta 48$. The proton spectrum (Figure 14) has significant peaks at $\delta 3.1,3.4,4.5$, and 4.8, and the cross peak at 3.4/3.6. Indeed both carbon and proton spectra are almost identical to those of sample 63, Hymenaea sp., and quite similar to those of sample 473, H. courbaril (compare Figures 5 and 6). Sample 1541 is from an unprovenanced Costa Rican source. Its carbon spectra resemble the Mexican and older Dominican sources, with very small exomethylene resonances and the usual saturated region. The spectrum with dipolar polar dephasing has the diagnostic Group D three-peak appearance. Unexpectedly, the sample was insoluble in chloroform and gave no proton results. 


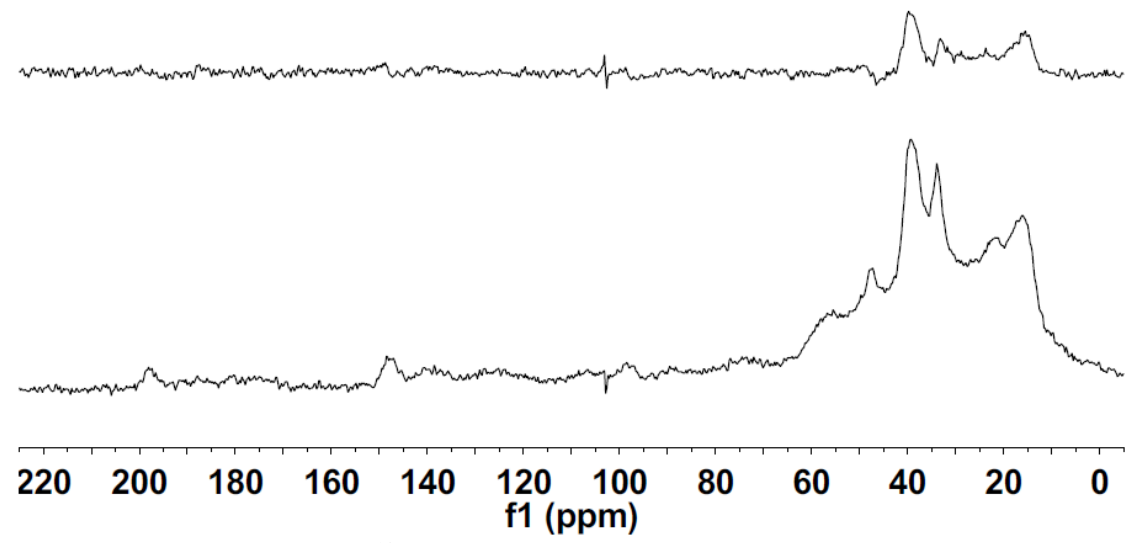

Figure 13. The $75.4 \mathrm{MHz}{ }^{13} \mathrm{C}$ NMR spectrum (lower) with complete decoupling and (upper) with dipolar dephasing of sample no. 1035, from San José, Costa Rica, from the collection of the National Museum of Natural History, Department of Paleobiology, sample no. 87624.

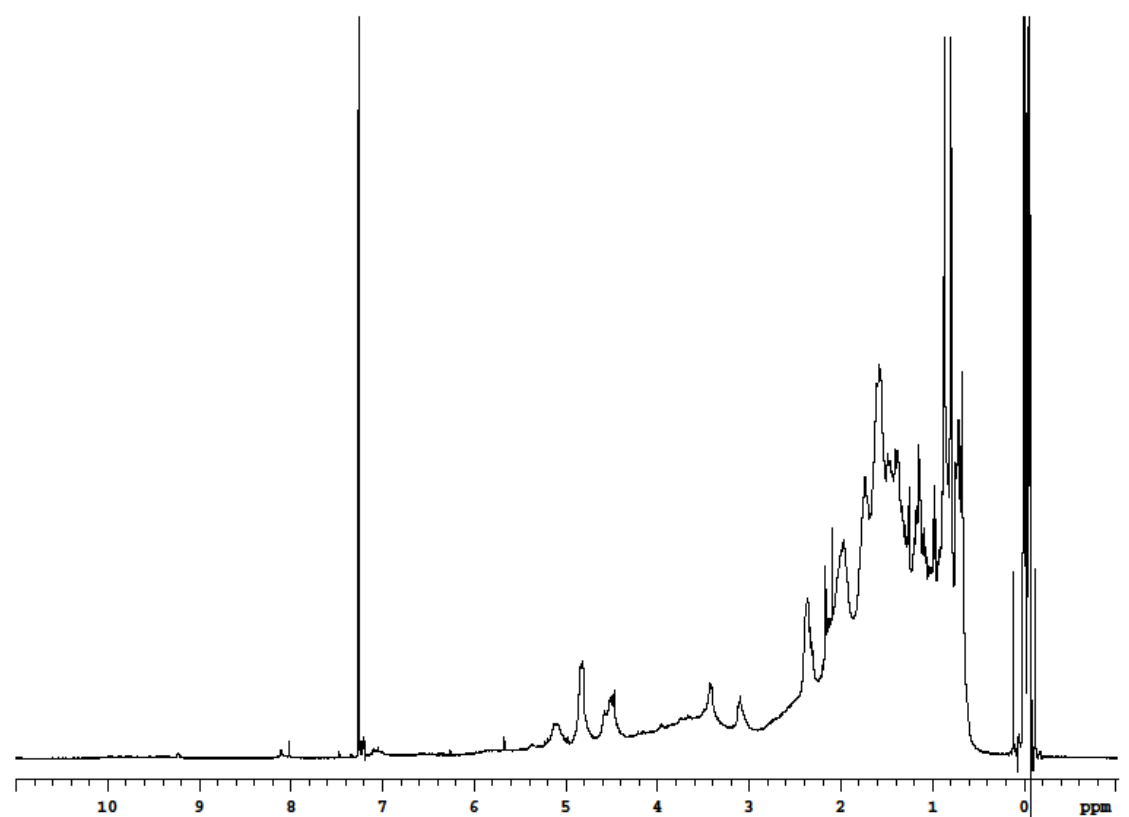

Figure 14. The $400 \mathrm{MHz}{ }^{1} \mathrm{H}$ spectrum in $\mathrm{CHCL}_{3}$ of sample no. 1035, from San José, Costa Rica. 
Samples from Belize, El Salvador (San Andrés), and one from Costa Rica appear to be genuine amber, but another sample from Costa Rica is a modern resin or copal. Langenheim (2003) has stated that Dominican amber was not traded outside of Hispaniola in pre-Colombian times. She also has suggested that Costa Rican amber could have been traded from Chiapas sources. A Mexican source is consistent with our spectra of all three Central American materials, although Dominican sources also are consistent with the spectroscopic evidence and thus should not be ruled out as a potential provenance.

\section{Colombia}

Sources of fossilized resin from Colombia have been known since early colonial times. Unfortunately, there is frequent ambiguity as to whether the materials are modern resin, copal, or amber. Langenheim (1990) suggested Pliocene to Pleistocene dates (5.3-2.6 Ma and 2.6 Ma to 11,700 BP, respectively) for Colombian amber. Pleistocene dates straddle the concepts of amber and copal. $\mathrm{A}^{14} \mathrm{C}$ date on a sample from the state of Santander yielded an age of 200 years (Clifford et al. 1997) corresponding to recent resin. This sample may be exceptional or influenced by modern materials mixed with ancient. Other sources have given ages from the Pleistocene to the Lower Miocene (20 Ma). Sources generally are Andean.

Our first Colombian samples were unprovenanced and proved to be recent resins or copals. Samples 173, 174, and 183 all gave carbon spectra with very strong exomethylene resonances and a very rich saturated region. With dipolar dephasing, the alkenic resonances at $\delta 140$ and 148 survive, along with strong resonances in the saturated region at $\delta 15$ (two peaks), 38 (two peaks), and 47. The proton spectrum of sample 183 has the classic resin/copal pattern, with significant peaks at $\delta 3.1,3.4,4.5$, and 4.5 , the cross peak at 3.4/3.7, and the classic saturated pattern. A sample (766) (Figures 15 and 16) from Girón, near Bucaramanga, Santander, has the same pattern of carbon and proton spectra and must be classified as recent material, as do samples from Medellín, Antioquía (767), Santander department (otherwise unprovenanced) (950), unprovenanced Colombia (1470), El Cerrejón Norte (a coal mine in La Guajira department) (the sample carried a Pleistocene date) (1512), and unprovenanced Colombia (1516, 1517 , called copal). Sample 950 had been given a Miocene date, which clearly was in error. All gave spectra characteristic of modern resins or copals. 

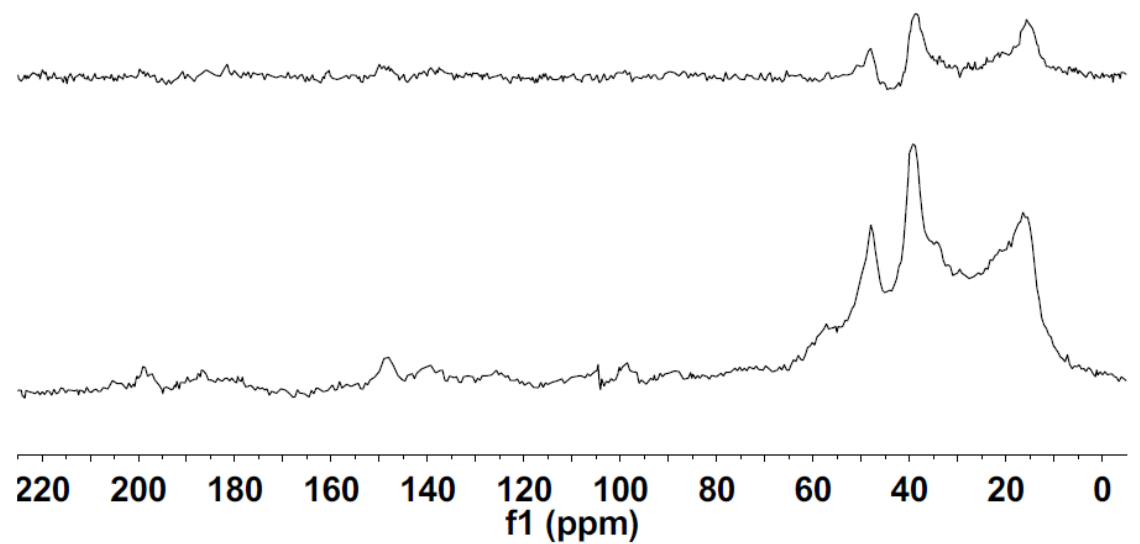

Figure 15. The $75.4 \mathrm{MHz}{ }^{13} \mathrm{C}$ NMR spectrum (lower) with complete decoupling and (upper) with dipolar dephasing of sample no. 766, from Girón, near Bucaramanga, Santander, Colombia, called copalite, from the National Museum of Natural History, sample no. R7313.

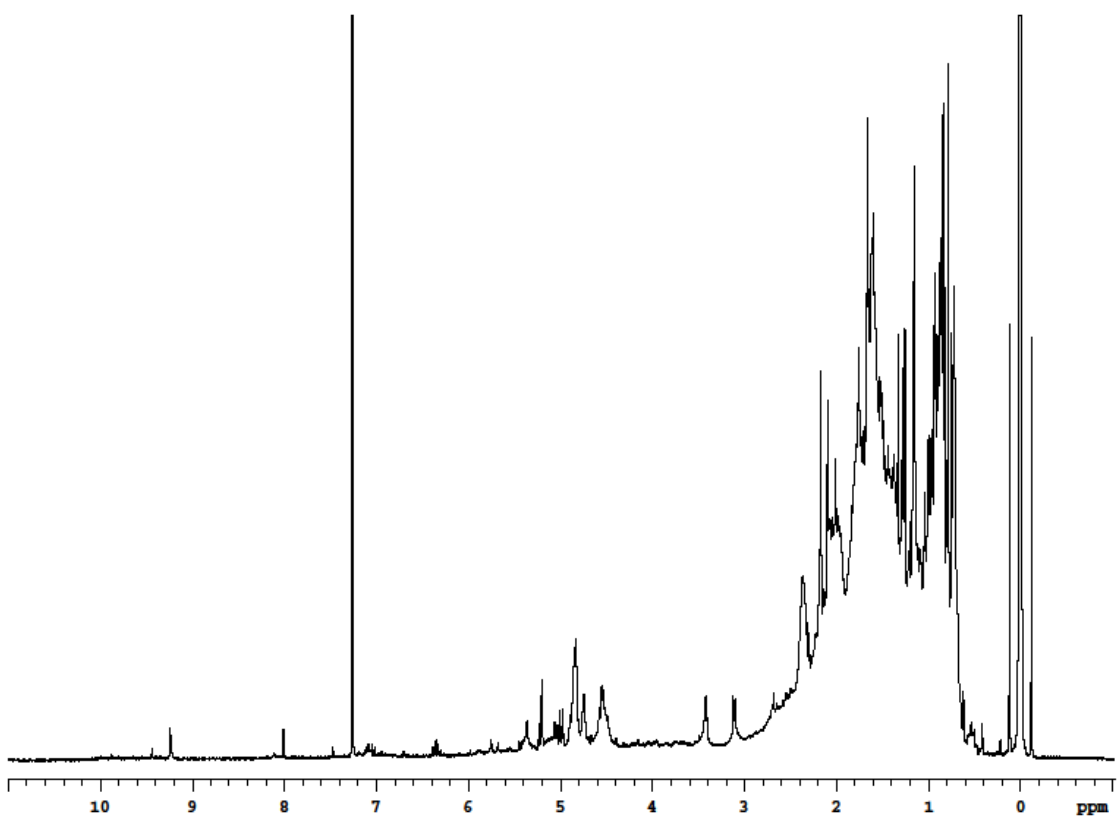

Figure 16. The $400 \mathrm{MHz}{ }^{1} \mathrm{H}$ spectrum in $\mathrm{CHCl}_{3}$ of sample no. 766, from Girón, near Bucaramanga, Santander, Colombia.

Sample 1471 was characterized as "green amber, autoclaved, Colombian copal," and it proved to be much harder than the other Colombian samples. The 
term "green" can refer to the color (it was light yellowish green) or to its age or state of maturity. Thus a green amber could mean a copal. The carbon spectrum has very weak exomethylene resonances and broad saturated peaks, often suggestive of amber. The proton spectrum lacks the four alkenic peaks and the COSY cross peak that are diagnostic for recent materials or copal. Normally, such a pattern would indicate fossilized amber, but the effects of autoclaving could be the cause of the altered pattern, as strong heating may simulate the process of maturation.

Four samples (1522-1525) are quite different from the others, in that they were obtained from an archaeological context, the site of Nahuange located in the coastal portion of north-central Colombia. J. Alden Mason of the Field Museum carried out excavations in 1922-1923 in this and other sites in the Santa Marta region, which is situated on the coastal state of Magdalena. The occupation of this site is associated with a proto-Tairona phase dated between AD 130 and 800-1000 (Bray 2003). The field report of the original excavations at this site (Mason, 1931, p. 228) states that "Objects of resin or amber are so exceedingly rare in America that their occurrence has been questioned." He also states that about 40 cylindrical beads were "mainly bought in Bonda and Taganga." He says they were fragile and many were broken, as were the samples we obtained. Their description corresponds to the material we obtained, and his cited Field Museum acquisition number, 152947, is identical to that supplied to us with the samples. In addition, Mason (1931:228) reported six petaloid pendants of amber found in a pottery vessel in the stone grave at Nahuange. According to the report, "Mr. James B. McNair of Field Museum [identified the source] as probably Hymenaea, possibly sweetgum (liquidambar), not a coniferous tree." Most importantly, he suggests that "They were probably molded while soft around a core or stem."

Unfortunately, the bead fragments from this site proved to be insoluble in chloroform and did not yield proton spectra. This is unusual behavior for most ambers and may have resulted from the process of converting the raw amber to a bead, that is, from heating, which accelerated their maturation. The carbon spectra (Figure 17) lack all exomethylene resonances. The very broad saturated resonance has the dominant peak at $\delta 38$ and a strong secondary peak at $\delta 23$, with several shoulders. With dipolar dephasing, the spectra contain the three diagnostic peaks at $\delta 16$ (two peaks), 37, and 45 for Group D. Peaks are clearly absent that would be necessary for materials from the other NMR groups of fossilized resin. The spectra are not those of a typical modern resin or copal. We are left with two possibilities. Either the materials are fossilized amber, or the process of heating to allow molding achieved sufficient maturation that the spectra resemble that of amber, as probably was the case with the green amber sample (1541). Given the universal absence of truly fossilized materials in our other Colombian samples, if the Santa Marta beads indeed are fossilized resin, 
they would have to have been made from material obtained by trade or were trade items themselves.

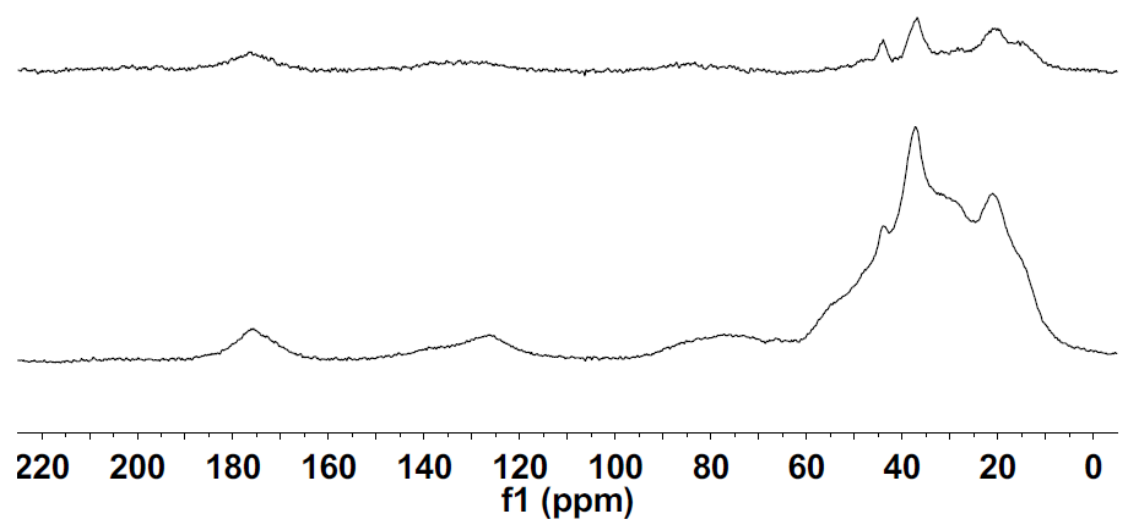

Figure 17. The $75.4 \mathrm{MHz}{ }^{13} \mathrm{C}$ NMR spectrum (lower) with complete decoupling and (upper) with dipolar dephasing of sample no. 1427, part of a disintegrated amber bead obtained by J. A. Mason in 1922-3 from the markets of Bonda or Taganga near the archaeological site of Santa Marta, Magdalena, Colombia, Field Museum, sample no. 152947.31.

\section{Other South American Sources}

We have three samples from Venezuela, none of which gave spectra characteristic of modern resins or copals. Sample 896 (Figures 18 and 19) was well provenanced, as coming from the Urumaco formation in the Venezuelan state of Falcón, quoted as Pliocene (2.6-5.3 Ma) but normally dated as Late Miocene (5.3-11.7 Ma). The spectral evidence confirms the material to be fossilized resin. The carbon spectrum lacks exomethylene resonances and has broad saturated resonances. The absence of exomethylene peaks makes it more similar to the Mexican than the Dominican samples. The spectrum with dipolar dephasing has the universal Group D pattern of three peaks. The proton spectrum lacks the peaks in the unsaturated region associated with modern resins and copals, and the pattern in the saturated region is normal for Group D. The spectra of samples 922 of unknown Venezuelan provenance and 1456 (Barquisimeto, called "family copal" by Royal Mapes) are intermediate in nature. Both carbon spectra have weak exomethylene resonances and somewhat broad saturated resonances, and the spectra with dipolar dephasing are normal for Group D or its modern counterparts. Both proton spectra have very weak resonances at $\delta 3.1$ and 3.4, a clear cross peak at 3.2/3.5, and weak peaks at $\delta 4.5$ and 4.8. These materials are not modern resins, but either copals (up to $1 \mathrm{Ma}$ ) or possible young ambers (Pliocene). 

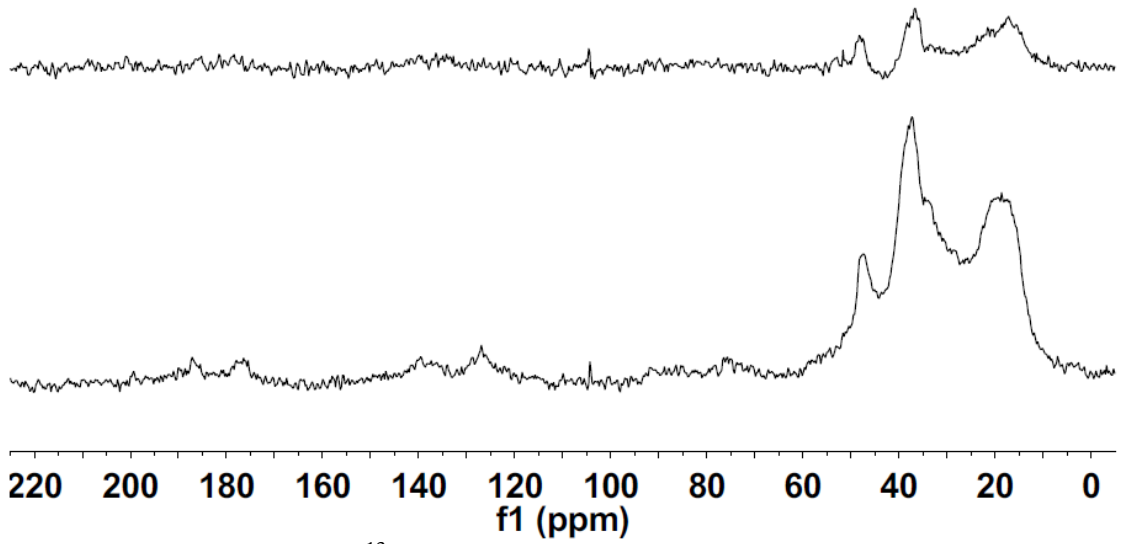

Figure 18. The $75.4 \mathrm{MHz}{ }^{13} \mathrm{C}$ NMR spectrum (lower) with complete decoupling and (upper) with dipolar dephasing of sample no. 896, from Estado Falcón, Venezuela, Urumaco formation, Pliocene, from the collection of Daniel Fisher, obtained in 1972, J. H. Langenheim sample no. 5772 from the New York Botanical Garden, sample no. 00202181 .

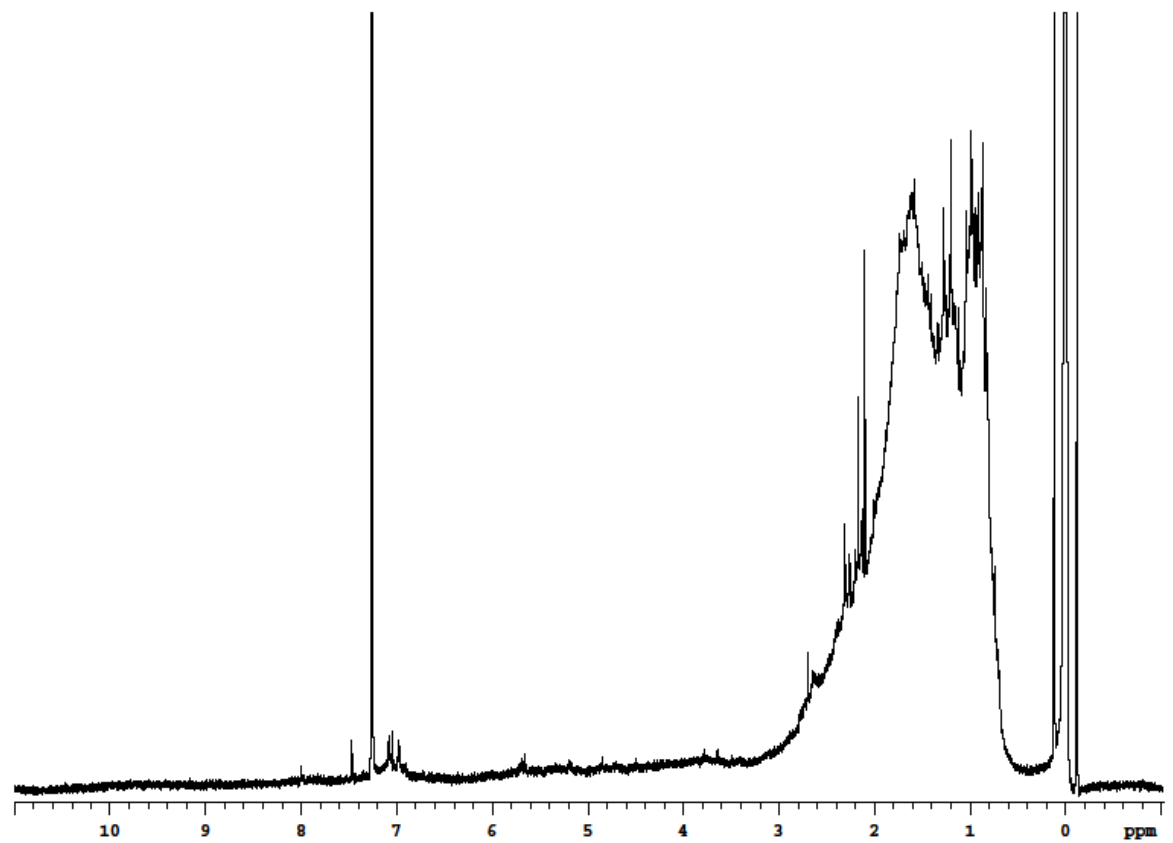

Figure 19. The $400 \mathrm{MHz}{ }^{1} \mathrm{H}$ spectrum in $\mathrm{CHCl}_{3}$ of sample no. 896, from Estado Falcón, Venezuela. 
We have samples from several other South American sites. Sample 246 from Guyana gives the typical carbon and proton spectra of a modern resin or copal, as do samples 249 and 1427 from Uruguay (Figures 20 and 21) and samples 251, 921 (Mato Grosso), 984 ("copal"), 1426 (Mato Grosso), and 1514 (the Amazon) from Brazil. Samples 765 from near Guayaquil, Ecuador ("guayaquilite"), and 1488 from Perú gave spectra that were not indicative of resinous materials. There were large peaks in the region of electronwithdrawing groups, $\delta 60-90$. These materials are something other than amber, possibly synthetic. Samples 521 and 522 were unprovenanced, only with the designation of South America, and both had been autoclaved. The carbon spectra lack exomethylene resonances, and the saturated region is somewhat broadened, both characteristics of fossilized resin. The proton spectra lack the characteristic alkenic resonances in the unsaturated region and the diagnostic cross peak for modern resins or copals. These results are consistent either with a fossilized resin or with alterations in the spectra caused by autoclaving, to produce a pattern normally characteristic of higher maturation. All samples from central and southern South America proved to be modern, copal, or heattreated. None gave characteristics of fossilized resin.
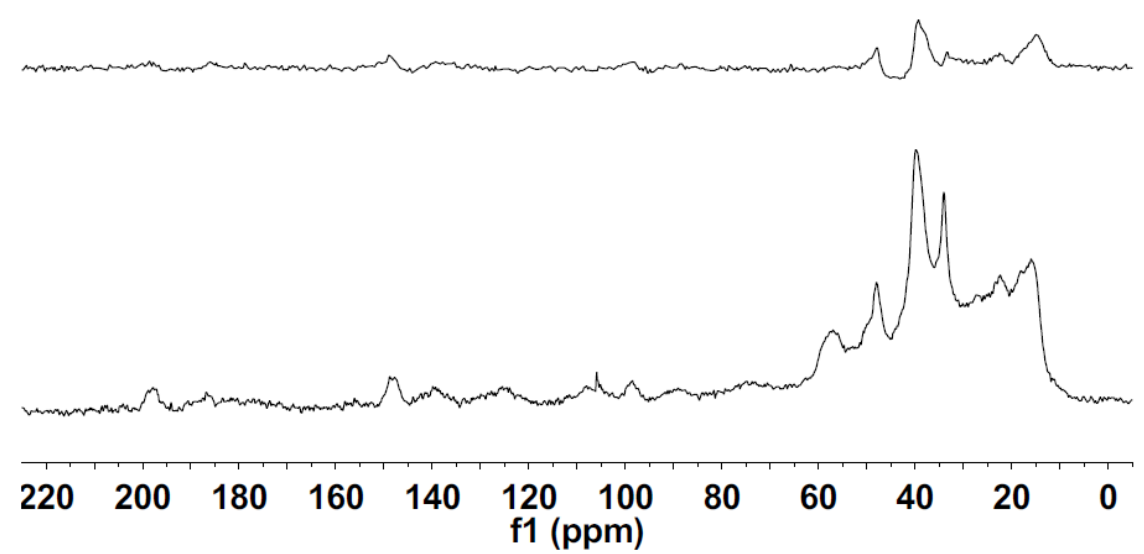

Figure 20. The $75.4 \mathrm{MHz}{ }^{13} \mathrm{C}$ NMR spectrum (lower) with complete decoupling and (upper) with dipolar dephasing of sample no. 1427, from Uruguay, from Crystal Triad, sample no. 213-433-provided by Patrick Craig. 


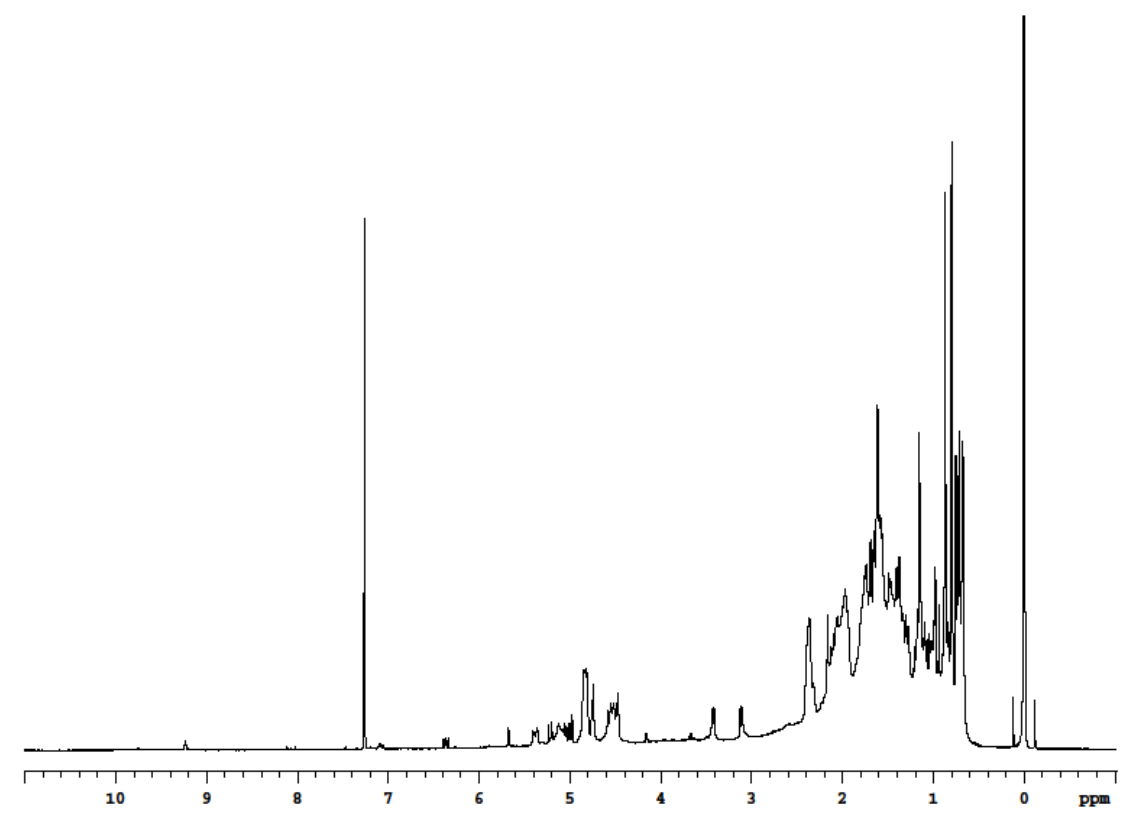

Figure 21. The $400 \mathrm{MHz}{ }^{1} \mathrm{H}$ spectrum in $\mathrm{CHCl}_{3}$ of sample no. 1427, from Uruguay.

\section{Conclusions}

Samples from the Gulf Coast of the United States are from Group A, as is the case for almost all materials from the more northerly part of the continent, with the exception of a small number of Group B ambers. For sources south of the Sonoran desert, samples are all from Group D. Many samples with the appearance of amber proved to be modern resins or copal. Although NMR analysis always can identify modern or semi-fossilized materials, the effects of heating or autoclaving can result in spectra that simulate those of fossilized or highly mature materials. Thus some of the apparent fossilized materials may be more recent. Truly fossilized materials have been confirmed from the Dominican Republic, Puerto Rico, the Mexican state of Chiapas, Belize, El Salvador, Costa Rica, Colombia, and Venezuela. Of these samples, material documented as coming from existing mining sites came only from the Dominican Republic, Chiapas, and northwestern Venezuela. In the absence of confirmed mining sites at their sources, the archaeological materials from Puerto Rico and Colombia may be objects of long-distance trade. From simplistic geographical considerations of nearness, Chiapas was a likely supplier for Costa Rica and the Dominican Republic for Puerto Rico and Colombia. The presence of exomethylene resonances in the carbon spectra of the archaeological amber from Puerto Rico is most similar to the spectra from the Dominican Republic. 
Amber from the mining sources in Mexico and Venezuela generally lacked such resonances. The archaeological amber from Colombia entirely lacked exomethylene resonances, consonant with Venezuelan or unlikely Mexican sources. This conclusion, however, is tempered by the character of the Colombia materials, which were reported to have been heated if not melted. Such treatment can simulate maturation and lead to changes such as loss of the exomethylene resonances. If such occurred, it is still possible that the Colombian materials came from Hispaniola.

The possible presence of amber from Hispaniola in Colombia would have important archaeological implication. The lack of evidence of amber sources and artifacts from archaeological contexts of the Lesser Antilles and northeastern Venezuela seems to point to the long-distance maritime movement of this material between the Greater Antilles and Colombia. The observation is consonant with the documented existence of macro-regional webs of interaction in pre-Columbian times through which a myriad of plants, animals, materials, information, and technologies circulated in a multi-vectorial fashion between the islands and the surrounding continents in pre-Columbian times (e.g. García Casco et al. 2013; Laffoon et al. 2014; Rodríguez Ramos 2010; Rodríguez Ramos and Pagán Jiménez 2006).

Acknowledgments

The authors are grateful to the Welch Foundation (Departmental Grant No. W-0031), the Camille and Henry Dreyfus Senior Scientist Mentor Program, and The Pennsylvania State University, York Campus, for financial support of this research.

\section{Literature Cited}

Alegría, R. E. 1980. Cristóbal Colón y el Tesoro de los Indios Taínos de La Española. Serie Monográfica. Fundación García-Arévalo, Inc. Santo Domingo, Dominican Republic. 48 pp.

Anderson, K. B. and W. Bray. 2006. The Amber of El Dorado: Class Ib Archaeological Ambers Associated with Laguna Guatavita. Archaeometry 48:633-640. http://dx.doi.org/10.1111/j.1475-4754.2006.00277.x

Bray, W. 2003. Gold, Stone, and Ideology: Symbols of Power in the Tairona Tradition of Northern Colombia. pp. 301-344. In, Gold and Power in Ancient Costa Rica, Panama, and Colombia, J. Quilter and J. W. Hoopes (Editors). Dumbarton Oaks Research Library and Collection, Washington, District of Columbia, USA. 429 pp.

Bray, P. S. and K. B. Anderson. 2009. Identification of Carboniferous (320 million years old) class Ic amber. Science 326:132-134. http://dx.doi.org/10.1126/science.1177539

Clifford, D. J., P. G. Hatcher, R. E. Botto, J. V. Muntean, B. Michels, and K. B. Anderson. 1997. The nature and fate of natural resins in the geosphere-VIII. NMR and Py-GC-MC characterization of soluble labdanoid polymers, isolated from Holocene class I resins. Organic Geochemistry 27:449-464. http://dx.doi.org/10.1016/S0146-6380(97)00043-0

Fraquet, H. 1987. Amber. Butterworths. London, England, UK. 176 pp.

García Casco, A., S. Knippenberg, R. Rodríguez Ramos, G. Harlow, C. L. Hofman, J. C. Pomo, and I. Blanco Quintero. 2013. Pre-Columbian jadeitite artifacts from the Golden Rock Site, St. Eustatius, Lesser Antilles: Implications for potential source regions and long-distance exchange networks in the Greater Caribbean. Journal of Archaeological Science 40:31533169. http://dx.doi.org/10.1016/j.jas.2013.03.025

Iturralde-Vinent, M. A. 2001. Geology of the amber-bearing deposits of the Greater Antilles. Caribbean Journal of Science 37(3-4):141-166. 
Iturralde-Vinent, M. A. and E. Harstein. 1998. Miocene amber and lignitic deposits in Puerto Rico. Caribbean Journal of Science 34(3-4):308-312.

Labandeira, C. C. 2014. Amber. pp. 163-215. In, Reading and Writing of the Fossil Record: Preservational Pathways to Exceptional Fossilization. Laflamme, M., J. Schiffbauer, and S. Darroch (Editors). Paleontological Society Papers 20. Paleontological Research Institute. Ithaca, New York, USA. 313 pp.

Laffoon, J., R. Rodríguez Ramos, L. Chanlatte Baik, Y. Narganes Storde, M. Rodríguez López, G. R. Davies, and C. L. Hofman. 2014. Long-distance exchange in the precolonial CircumCaribbean: a multi-isotope study of animal tooth pendants from Puerto Rico. Journal of Anthropological Archaeology 35:220-233. http://dx.doi.org/10.1016/j.jaa.2014.06.004

Lambert, J. B., J. S. Frye, and G. O. Poinar, Jr. 1985. Amber from the Dominican Republic: analysis by nuclear magnetic resonance spectroscopy. Archaeometry 27:43-51. http://dx.doi.org/10.1111/j.1475-4754.1985.tb00345.x

Lambert, J. B., J. S. Frye, T. A. Lee, Jr., C. J. Walsh, and G. O. Poinar, Jr. 1989. Analysis of Mexican amber by carbon-13 NMR Spectroscopy. pp. 381-388. In, Archaeological Chemistry IV. Developed from a symposium sponsored by the Division of History of Chemistry at the 193rd meeting of the American Chemical Society. Denver, Colorado, USA. April 5-10, 1987. Allen, R. O. (Editor). Advances in Chemistry Series. No. 220. American Chemical Society. Washington, District of Columbia, USA. 508 pp.

Lambert, J. B., S. C. Johnson, and G. O. Poinar, Jr. 1995. Resin from Africa and South America: Criteria for distinguishing between fossilized and recent resin based on NMR spectroscopy. pp. 193-202. In, Amber, Resinite, and Fossil Resins: Developed from a symposium sponsored by the Division of Geochemistry at the 208th National Meeting of the American Chemical Society, Washington, District of Columbia, USA. August 21-25, 1994. Anderson, K. B. and J. C. Crelling (Editors). ACS Symposium Series. No. 617. American Chemical Society. Washington, District of Columbia, USA. 297 pp.

Lambert, J. B., Y. Wu, and J. A. Santiago-Blay. 2002. Modern and Ancient Resins from Africa and the Americas. pp. 64-83. In, Archaeological Chemistry: Materials, Methods, and Meaning. K. A. Jakes (Editor). ACS Symposium Series. No. 831. American Chemical Society. Washington, District of Columbia, USA. Distributed by Oxford University Press. Oxford, England, UK. 261 pp.

Lambert, J. B., J. A. Santiago-Blay, and K. B. Anderson. 2008. Chemical signatures of fossilized resins and recent plant exudates. Angewandte Chemie, International Edition 47:9608-9616. http://dx.doi.org/10.1002/anie.200705973

Lambert, J. B., E. A. Heckenbach, A. E. Hurtley, Y. Wu, and J. A. Santiago-Blay. 2009. Nuclear Magnetic Resonance spectroscopic characteristics of legume exudates. Journal of Natural. Products 72:1028-1035. http://dx.doi.org/10.1021/np900188j

Lambert, J. B., C. Y.-h. Tsai, M. C. Shah, A. E. Hurtley, and J. A. Santiago-Blay. 2012. Distinguishing amber classes by Proton Magnetic Resonance spectroscopy. Archaeometry 54:332-348. http://dx.doi.org/10.1111/j.1475-4754.2011.00625.x

Lambert, J. B., A. J. Levy, J. A. Santiago-Blay, and Y. Wu. 2013. Nuclear Magnetic Resonance (NMR) Characterization of Indonesian Amber. Life: The Excitement of Biology 1:136-155. http://dx.doi.org/10.9784/LEB1(3)Lambert.02

Lambert, J. B., J. A. Santiago-Blay, Y. Wu, and A. J. Levy. 2014. Examination of amber and related materials byNMR spectroscopy. Magnetic Resonance in Chemistry. Article first published online: 31 AUG 2014 | DOI: 10.1002/mrc.4121 , http://dx.doi.org/10.1002/mrc.4121

Langenheim, J. H. 1990. Plant Resins. American Scientist 78:16-24.

Langenheim, J. H. 2003. Plant Resins. Timber Press. Portland, Oregon, USA. 586 pp.

Lee Whiting, T. A. (Editor). 2005. Ámbar de Chiapas: Historia, Ciencia y Estética. Gobierno del Estado de Chiapas. Tuxtla Gutiérrez, Chiapas, Mexico. 276 pp.

Lowe, L. S. 2001. Evidencias arqueológicas del ámbar en el área Maya: usos y distribución. pp. 772-785. In, XIV Simposio de Investigaciones Arqueológicas en Guatemala [Ponencias]. 2000. Laporte, J. P., A. C. Suasnávar, and B. Arroyo (Editors). Museo Nacional de Arqueología y Etnología. Asociación Tikal. Guatemala City, Guatemala. 28 pp. 
Langenheim, J. H. 1990. Plant Resins. American Scientist 78:16-24.

Langenheim, J. H. 2003. Plant Resins. Timber Press. Portland, Oregon, USA. 586 pp.

Lee Whiting, T. A. (Editor). 2005. Ámbar de Chiapas: Historia, Ciencia y Estética. Gobierno del Estado de Chiapas. Tuxtla Gutiérrez, Chiapas, Mexico. 276 pp.

Lowe, L. S. 2001. Evidencias arqueológicas del ámbar en el área Maya: usos y distribución. pp. 772-785. In, XIV Simposio de Investigaciones Arqueológicas en Guatemala [Ponencias]. 2000. Laporte, J. P., A. C. Suasnávar, and B. Arroyo (Editors). Museo Nacional de Arqueología y Etnología. Asociación Tikal. Guatemala City, Guatemala. 28 pp.

Langenheim, J. H. 1990. Plant Resins. American Scientist 78:16-24.

Langenheim, J. H. 2003. Plant Resins. Timber Press. Portland, Oregon, USA. 586 pp.

Lee Whiting, T. A. (Editor). 2005. Ámbar de Chiapas: Historia, Ciencia y Estética. Gobierno del Estado de Chiapas. Tuxtla Gutiérrez, Chiapas, Mexico. 276 pp.

Lowe, L. S. 2001. Evidencias arqueológicas del ámbar en el área Maya: usos y distribución. pp. 772-785. In, XIV Simposio de Investigaciones Arqueológicas en Guatemala [Ponencias]. 2000. Laporte, J. P., A. C. Suasnávar, and B. Arroyo (Editors). Museo Nacional de Arqueología y Etnología. Asociación Tikal. Guatemala City, Guatemala. 28 pp.

Mason, J. A. 1931. Archaeology of Santa Marta, Colombia: the Tairona Culture. Field Museum Press. Chicago, Illinois, USA. 256 pp. http://dx.doi.org/10.5962/bhl.title.1415

Poinar, G. Jr., J. B. Lambert, and Y. Wu. 2007. Araucarian source of fossiliferous Burmese amber: Spectroscopic and anatomical evidence. Journal of the Botanical Research Institute of Texas 1:449-455.

Rice, P. C. 2006. Amber: The Golden Gem of the Ages. Fourth Edition. AuthorHouse. Bloomington, Indiana, USA. 289 pp.

Rodríguez López, M. 1991a. Early trade networks in the Caribbean. pp. 306-314. In, Proceedings of the 14th International Congress for Caribbean Archaeology. Barbados. 694 pp.

Rodríguez López, M. 1991b. Excavaciones en Punta Candelero, Puerto Rico: Informe preliminar. pp. 605-627. In, Proceedings of the 13th International Congress for Caribbean Archaeology. Curaçao. $976 \mathrm{pp}$.

Rodríguez Ramos, R. 2010. Rethinking Puerto Rican Precolonial History. Caribbean Archaeology and Ethnohistory Series. L. Antonio Curet (Editor). University of Alabama Press. Tuscaloosa, Alabama, USA. 267 pp.

Rodríguez Ramos, R. and J. Pagán Jiménez. 2006. Interacciones multivectoriales en el CircumCaribe precolonial: un vistazo desde las Antillas. Caribbean Studies 34(2):103-143.

Sanoja, M. and I. Vargas. 1967. Proyecto Arqueología del Occidente de Venezuela. Universidad Central de Venezuela. Revista Economía y Ciencias Sociales. Número 2 (April-June), Año 9. Primer Informe. Caracas, Venezuela. 36 pp.

Sanoja, M. and I. Vargas-Arenas. 1999. Orígenes de Venezuela. Regiones geohistóricas aborígenes hasta 1500 d.c. Comisión Presidencial del Vto. [Quinto] Centenario de Venezuela. Caracas, Venezuela. 217 pp.

Schlee, D. and W. Glöckner. 1978. Bernstein. Stuttgarger Beiträge zur Naturkunde Serie C 8:1-72.

Valcárcel Rojas, R. 2012. Interacción Colonial en Un Pueblo de Indios Encomendados. El Chorro de Maita, Cuba. Ph. D. Dissertation. Faculty of Archaeology, University of Leiden, The Netherlands. 461 pp.

Vávra, N. 2009. Amber, fossil resins and copal—contributions to the terminology of fossil plant resins. Denisia 26:213-222.

Vega, B. 1987. Los metales y los aborígenes de La Española. pp. 31-57. In, Santos, shamanes y zemíes. Fundación Cultural Dominicana. Santo Domingo, Dominican Republic. 185 pp.

Veloz Maggiolo, M., E. Ortega, P. Pina Peña, R. Rimoli, and F. Luna Calderón. 1972. El cementerio de La Unión. Provincia Puerto Plata. Boletín del Museo del Hombre Dominicano 2:130-156.

Wagner, E. 1984. Relaciones prehispánicas de Venezuela. Asociación Venezolana de Arqueología, Asociación Venezolana para el Avance de la Ciencia. Caracas, Venezuela. 87 pp.

Wassen, S. H. 1955. Algunos datos del comercio precolombino de Colombia. Instituto Colombiano de Antropología. Bogotá, Colombia. 23 pp. 